
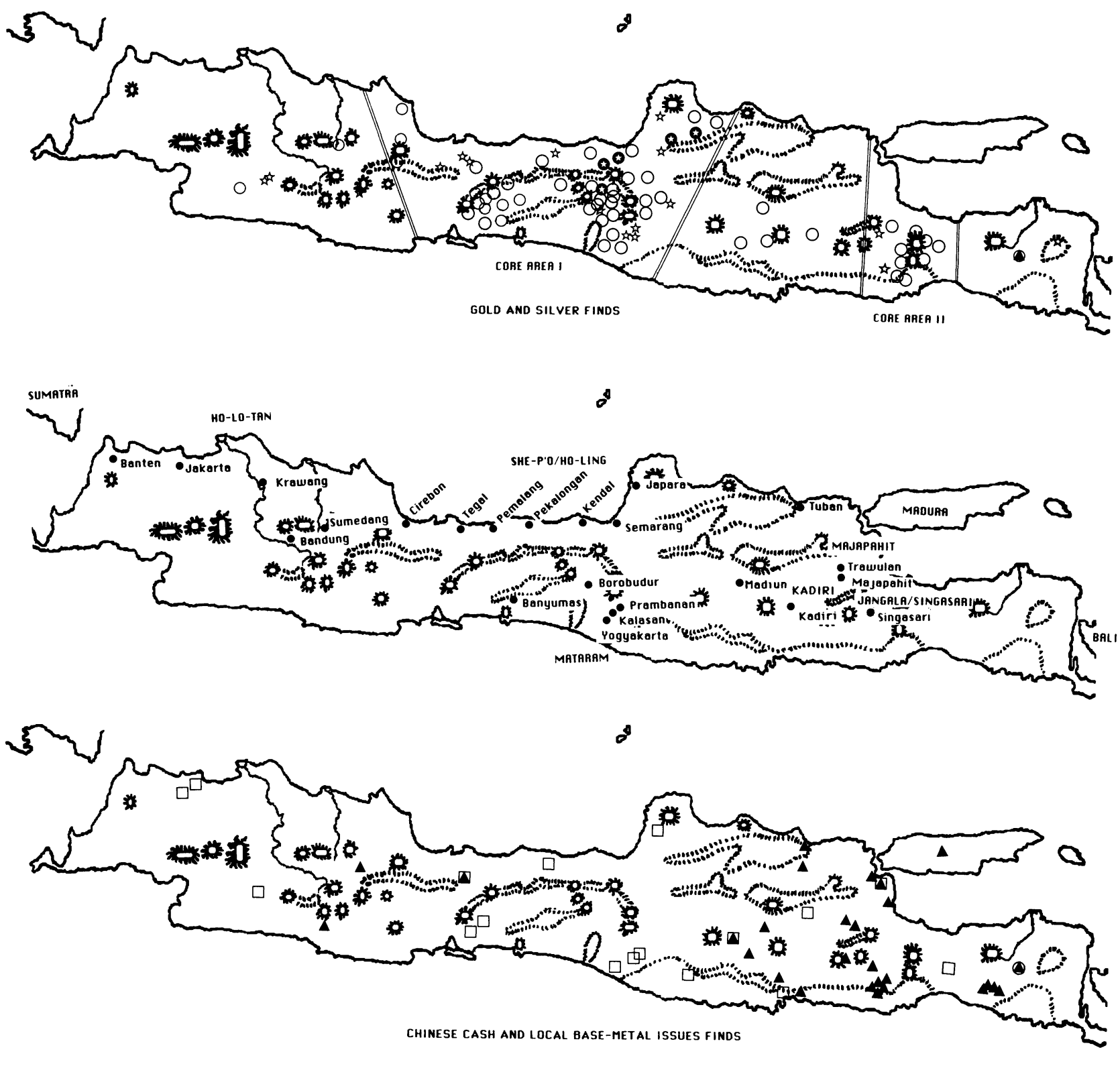

\title{
CLASSICAL JAYA
}

(THE LOCATION OF EACH FIND IS APPROXIMATE)

OSILVER FINDS

TGOLD FINDS

* MIXED GOLD AND SILVER FINDS

QMIXED CHINESE CASH AND SILVER FINDS

A CHINESE CASH FINDS

$\square$ LOCAL BASE METAL ISSUES FINDS

$\square$ MIXED CHINESE CASH AND BASE METAL FINDS 


\title{
MONETARY DEVELOPMENTS IN JAVA BETWEEN THE NINTH AND
} SIXTEENTH CENTURIES: A NUMISMATIC PERSPECTIVE*

Robert S. Wicks

\begin{abstract}
- . this place [called Java,] surrounded by the sea, is full of movable and immovable wealth and blessed with treasure, and is one where it rains pearls, and gold and silver coin and goods of the most precious kind. The creative power of the Almighty has perfumed this place and its surroundings with the breath of aloe and of cloves; in the houses and the districts the parrots cry in Arabic: "I am a garden, whose glories and pleasures are envied by every paradise. . . "

Wāssāf, "The Conquest of the Island of Java," completed ca. 1299-1300.1
\end{abstract}

\section{Introduction}

The fourteenth century is a critical period of transition in Southeast Asian political and economic history. The region is just recovering from a series of Mongol incursions--Nan-chao in 1253, Hanoi in 1257, Hue and Burma in the 1280s, and Java in 1293. Cambodia by this time is slipping into what has been called its "dark ages." The glory of the Indonesian empire of Sriwifaya is past.

* Research for this study was made possible by support from the American Numismatic Society, the Kress Foundation, and from Cornell University's Southeast Asia Program. The author's doctoral dissertation, "A Survey of Native Southeast Asian Coinage circa 450-1850: Documentation and Typology" (Cornel] University, May 1983) [henceforth "Survey of Coinage"] provides a comprehensive overview of Southeast Asian numismatics. This article is a revised and expanded version of portions of chapter six of that work.

The author would like to thank Mr. Joe Cribb of the British Museum, London [henceforth BM], Dr. Michael Bates of the American Numismatic Society, New York [henceforth ANS], Drs. A. F. Ros of the Museum voor Land- Taal- en Volkenkunde, Rotterdam [henceforth MLV], and Dr. Graham Pollard of the Fitzwilliam Museum, Cambridge [henceforth FM], for kindly allowing him to study their numismatic holdings, and Dr. Jan Wisseman Christie for providing the author with copies of her recent work on pre-Majapahit economic history.

Following numismatic practice, coin citations are generally presented in a shortened form, such as Millies (1871), Plate I, no. 3. A reference is cited in full at its first appearance.

1. Bertold Spuler, History of the Mongols Based on Eastern and Western Accounts of the Thirteenth and Fourteenth Centuries (Berkeley: University of California Press, 1972), PP. 168-69. 
The late thirteenth and early fourteenth centuries mark the political emergence of the Thai at Sukhothai, and, by the middle of the century, the establishment of Ayudhya (1351), the rise of Lan Sang, and invasions of upper Burma by the Shan. The founding of Majapahit in 1292 marks the beginning of a new era in Indonesian history. Islam is becoming an important religious and economic force in the region, witnessed by Samudra/Pasai's issuance of Southeast Asia's first Islamic gold coinage in the first quarter of the fourteenth century. 2

This article is concerned with Javanese monetary history during this critical period, documenting a dramatic shift from ritualized gold and silver coinage to low-value Chinese cash in the late thirteenth and early fourteenth centuries. Monetary developments prior to the fourteenth century are first reviewed, focusing on literary and numismatic evidence for local gold and sliver coinage. An examination is then made of a transitional phase in the decades around 1300 during which time Chinese cash comes to be favored over the earlier precious metal coins. A final section explores the uses of Chinese cash in Majapahit Java during the fourteenth, fifteenth, and early sixteenth centuries. An appendix lists finds of native gold and silver coinage and imported Chinese cash in premodern Java.

\section{Monetary Developments in Java Prior to the Fourteenth Century}

As early as 1889 Brandes complled a list of cultural achievements attained by the Javanese "before the arrival of the Hindus."3 Included among these achievements is an indigenous Javanese monetary system which was subsequently a)tered through Indian influence.

Although archaeological confirmation is presently lacking, there is ninth century epigraphic evidence for a ngtive iron bar currency called ikst wsi which

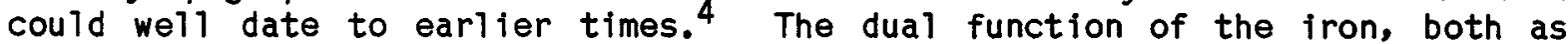
currency and for making tools, would represent an early stage in the monetization of the Javanese economy.

Monetary terms commonly found in $01 \mathrm{~d} J$ avanese stone and copper-plate inscriptions indicate the presence of an indigenous monetary terminology. These include, among others: kupang, an Indonesian weight equivalent to 0.6gm; atak, of uncertain value; and pirak and mas, local terms for silver and gold. 5 There

2. The best study of this series remains, J. Hulsoff Pol, "De gouden munten (mas) van noord-Sumatra," Jaarboek voor munt- en penningkunde 16 (1929): 1-32, supplemented by $C$. Scholten, "De gouden munten (mas) van noord-Sumatra (Addenda)," Jaarboek voor munt- en penningkunde 36, no. 2 (1949): 176-79 and Wicks, "Survey of Coinage," ch. 7.

3. See the commentary by Nicolaas J. Krom, "Indo-Javanese History" [trans. by Himansu Bhusan Sarkar]. Journal of the Greater India Soclety 12, pts. 1-2 (1956): 1-72, particularly PP. 52 and 57-58.

4. Jan Wisseman Christie, "Patterns of Trade in Western Indonesia: Ninth through Thirteenth Centuries A.D." (Ph.D. thesis, University of London, May 1982), p. 146.

5. Additional terms include the tahil, suvarna, and the kati among others. The reconstruction of 01d Javanese texts relies upon a body of knowledge not found in the inscriptions themselves. Contemporary inscriptions from Bali provide some 
are several terms which refer, if not specifically to coin, at least to money. The most common is artha, a Sanskritic word meaning both riches and money. Related words include those for "monetary share: (parmmasanya, parmasan) and "monetary value" (masuya). These are of Indonesian origin and contain the root for gold (mas).

References to gold and silver in 01d Javanese inscriptions are invariably expressed in abbreviated form. ${ }^{6}$ According to W. F. Stutterheim, the shortened forms for certain weights and values of gold and silver can be restored as follows: $k a$ (= kāti), su $(=$ suvarna), $m \bar{a}(=m \bar{a} a)$, and $k u(=k u p a n g)$. The relative values of these units are,

$$
\begin{aligned}
1 \text { kāti } & =16 \text { suvarna } \\
1 \text { käsāpaña } & =1 \text { suvarna }=16 \text { masa }=64 \text { kupang } \\
1 \text { mása } & =4 \text { kupang }
\end{aligned}
$$

Stutterheim further attempted to determine the precise gram equivalent for the units found in $01 \mathrm{~d}$ Javanese inscriptions. ${ }^{8} \mathrm{He}$ arrived at the following equivalencies:

$$
\begin{aligned}
\text { suvarna } & =38.601 \mathrm{gm} \\
\text { masa } & =2.412 \mathrm{gm} \\
\text { kupang } & =0.603 \mathrm{gm}
\end{aligned}
$$

His results for the value of masa are supported by a 1929 find of 126 gold Piloncito-type coins at Gianyar in Bal1.9 The heaviest coins weigh $2.5 \mathrm{gm}$, the 1 ightest $2.1 \mathrm{gm}$. When plotted to the nearest $0.1 \mathrm{gm}$ the following table results:

$\begin{array}{lccccccc}\text { Weight in Grams } & 2.0 & 2.1 & 2.2 & 2.3 & 2.4 & 2.5 & 2.6 \\ \text { Number of Specimens } & 0 & 1 & 6 & 10 & 64 & 45 & 0\end{array}$

This is further confirmed by weights of Sandalwood Flower Class $E$ coins (discussed below) from central Java dating to the late eighth or early ninth century. 10

$\begin{array}{lccccc}\text { Weight in Grams } & 2.2 & 2.3 & 2.4 & 2.5 & 2.6 \\ \text { Number of Specimens } & 0 & 2 & 10 & 1 & 0\end{array}$

These Sandalwood Flower coins are commonly called mā-coins (mä-muntjes to Dutch writers), referring not only to the letter impressed on their surface, but also to the unit of the coins--specimens normally weigh $2.4 \mathrm{gms}$, or 1 masa.

insight. See Wicks, "Survey of Coinage," PP. 229-30 and Christie, "Patterns of Trade," Pp. 140-46 and corresponding notes.

6. For example, 2 kati 7 suvarna and 8 masa of gold and 1 masa of silver would read: mas ka 2 su 7 má 8 pirak má 1. In 1 ate inscriptions, particularly those inscribed after the first quarter of the tenth century, mas is abbreviated to ma, resulting $\mathrm{in}$, at first $\mathrm{glance}$, an impossible sequence: ma $k a 7$ su $12 \mathrm{ma} 10$.

7. Willem Frederik Stutterheim, "Oorkonde van Balitung uit 905 AD (Randoesari I)," Inscripties van Nederlandsch-Indie [henceforth IN-I] 1 (1940): 3-28, see p. 17; "Oorkonde van Dang Acarya Munindra uit 885 AD (Randoesari II)," IN-I I: 29-32, see p. 31 .

8. See note 7.

9. "Gewicht der in Gianjar (Bali) gevonden gouden Hindoe-munten," Oudheidkundig Verslag [henceforth OV] (1929), Bijlage B, Pp. 18 and 72.

10. Specimens examined by the author. 
The 01d Javanese monetary/weight terms are used in several different ways: 11

i) to refer to weights, e.g., "one prasāda voh ring weighing [brat] 1 suvarna";

ii) to specify value, e.g., "one buffalo of the value of [masuya] I suvarna";

iii) to specify the amount of gold or silver distributed during a feast, e.g.. "all of them received together silver 8 masa";

iv) to express the purchase price of a piece of 1 and, e.g., ". . land of the garden .. . was purchased . . for gold ka l ...";

v) to indicate the cost of specialized services, e.g., "the expense of marking out a free-hold: the gold that came to the rakryan (was) suvarna 4 . . "; and

vi) to specify dues payable to the ruler, e.g., "Its receipt shall be gold 8 mása and 2 wild doves [?] payable each year."

In addition to the presence of a standardized weight system, several monetary functions are immediately evident, including the use of precious metals as a medium of exchange ( $i v, v$ ), as a measure of value ( $i i$ ), and as a standard of deferred payment ( $v i$ ). 12 A comment by Philip Grierson seems particularly relevant to the early Javanese monetary situation:

The relatively high values of early monetary standards would be more satisfactorily explained by their being marks of wealth, since a man's reputation was largely determined by the size of his herds and his generosity in giving gold and silver ornaments to his retainers and friends. 13

Grierson's comment serves to emphasize a notable feature of early Javanese monetary standards--for the most part they involve large values, appropriate to temple donations and feasts of redistribution but unsuitable for everyday market transactions. Jan Wisseman Christie further points out that the large values expressed in 01d Javanese inscriptions invariably refer to the transactions or obligations of an entire village and not those of individuals. 14

In this regard, it is important to note that although masa and kupang are clearly part of the same monetary system, the 2.4 gram masa has a longer history in Java than the 0.6 gram kupang. Christie has remarked that "The earlier inscriptions--those from the 9th through the 11th century--speak mainiy of masa and tahil units; the kupang begins to appear in the 11th or 12th century in

11. Representative examples can be found in Himansu Bhusan Sarkar, Corpus of the Inscriptions of Java (Calcutta: Mukhopadhyay, 1971-72), vol. 1 and 2; oudJavaansche oorkonden [henceforth 0J0]. Nagelaten transscripties van wijlen Dr. Jan Laurens Andries Brandes Uitgegeven door Dr. Nicolaas J. Krom, Verhandelingen van het Bataviaasch Genootschap van Kunsten en Wetenschappen, v01. 60 (1913); Johannes Gijsbertus de Casparis, Prasasti Indonesia, vol. 2 (Bandung: Masa Baru, 1956); Roelof Goris, Prasasti Bali: inscripties voor Anak wungcu, 2 vols. (Bandung: Masa Baru, 1954).

12. Discussions of money include, Thomas F. Carney, The Economies of Antiquity (Lawrence, Kansas: Coronado Press, 1973), and Walter C. Neale, Monies in Societies (San Francisco: Chandle \& Sharp, 1976).

13. Philip Grierson. The Origins of Money (London: The University of London, Athlone Press, 1977), p. 21.

14. Christie, "Patterns of Trade," p. 145. 
port areas."15 This gradual adoption of smalier weight units is confirmed by the numismatic record. The earliest specimens of Javanese coins are 1 imited to the masa; by the twelfth century smaller unit coins, of one and two kupang, begin to appear. One could argue that the appearance of the kupang in port areas is the result of greater international trading contacts and a sign of increased marketization of the Javanese economy in the twelfth century as compared to earlier times. The issue of coins and markets is discussed further in the Conclusion of this article.

The sources of the gold and sliver used in early Java remain enigmatic. The flow of precious metals in this period of Southeast Asian history is still very poorly understood and it is unclear whether Java produced gold and silver sufficient for its monetary needs, received some from subordinate rulers elsewhere in the archipelago, or had to import both gold and silver from outside the region. It is entirely possible that at least a portion of Java's silver and gold was imported from neighboring areas such as Sumatra, Borneo, the Philippines, or the Malay Peninsula. A number of early Arabic authors refer to "mines of gold and silver" located on Sumatra or the Malay Peninsula. 16 In addition. Borneo and the Philippines have long histories of gold production and could have supplied Java's needs as wel1.17 There are indications that Java was a gold producer, and at times exported quantities of the precious metal. Java's earliest dated inscription, of $A D$ 732, notes that "There is a great island called Yava, abundantly supplied with rice-grains and other seeds and goldmines. - . "18 In the year 992 tribute from Java offered to the Chinese consisted of ivory, pearls, gold ingots, and various textiles. 19

The nature of archaeological discoveries of precious metals in early Java renders necessary a distinction between metallic currency, money, and coin. The most useful definitions for our purposes are those provided by Charles Seltman:

Metal when used to facilitate the exchange of goods is currency; currency when used according to specific weight standards is money; money stamped with a device is coin. Metal intrinsically valuable, weight deliberately adjusted, the mark or device of a responsible authority, all three are needed to make a coin. Mankind first learned to value, next to weigh and 1 ast of all to stamp metal; or, in other words, evolved from a barter a metal 1 ic currency 3 abandoned mere currency for money and then mere money for coinage. 20

The large number of gold and silver coins (standardized pieces of stamped metallic money) as well as coin-like pieces (irregular stamped ingots of high value, for hoarding purposes) of native manufacture discovered on the island is

15. Personal communication, September 12, 1985.

16. G. R. Tibbetts, A Study of the Arabic Texts Containing Material on SouthEast Asia (Leiden: Bril1, 1979), p. 37.

17. See, for example, Tom Harrisson and Stanley J. O'Connor, Gold and Megalithic Activity in Prehistoric and Recent West Borneo (Ithaca: Cornell Southeast Asia Program Data Paper, 1970).

18. Himansu Bhusan Sarkar, Corpus of the Inscriptions of Java lup to 928 A.D.I. vol. 1 (Calcutta, 1971-72), p. 20.

19. Hervey de Saint-Denys, Ethnographie des peuples Etrangers a la Chine... Ma Touan-Lin, vol. 2 (Geneva: George, 1883), p. 496.

20. Charles T. Seltman, Greek Coins, 2nd ed. (London: Methuen, 1955), p. 1. 
indicative of the importance of coinage in economic exchange from at least the early ninth century. Absolute numbers of coins from reported finds give some indication of the geographical extent and relative intensity of coin usage in early Java. (See map.) The following tables provide a summary of finds recorded in the Appendices.

\section{Silver Finds}

\section{Core Area I and Eastern Periphery}

Number of Finds: $51^{*}$

Number of Coins in a Single Find: High:

Low:

Average find:

Total Specimens Reported:
1512 coins single specimen 109 coins
Core Area II and Eastern Periphery

Number of Finds: $8 *$

Number of Coins in a Single Find: High:

Low:

Average find:

Total Specimens Reported:
353 coins

single specimen 60 coins

*As reported in Appendix A. Includes only those finds for which number of specimens recovered is known.

\section{Relative Size of Silver Finds}

Core Area I and Eastern Periphery

Number of Specimens per Find

$1-10 \quad 11-100$

Number of Finds

19

19

$101-200$

$201+$

Core Area II and Eastern Periphery

Number of Specimens per Find

Number of Finds

$1-10$

6

$11-100$

$101-200$

1

$201+$

1

Gold Finds

Core Area I and Western Periphery

Number of Finds: $17^{*}$

Number of Coins in a Single Find:

High:

Low:

Average find: 700 coins

Total Specimens Reported: single specimen 62 coins

1058
Core Area II and Eastern Periphery

Number of Finds: $4 *$

Number of Coins in a Single Find:

High: $\quad 135$ coins

Low: single specimen

Average find: 36 coins

Total Specimens Reported: $\quad 145$

*As reported in Appendix $B$. Includes only those finds for which number of specimens recovered is known.

\section{Relative Size of Gold Finds}

Core Area I and Western Periphery

Number of Specimens per Find

Number of Finds

Core Area II and Eastern Periphery

Number of Specimens per Find

Number of Finds

$\begin{array}{cccc}1-10 & 11-100 & 101-200 & 201+ \\ 14 & 1 & 0 & 2\end{array}$

$\begin{array}{cccc}1-10 & 11-100 & 101-200 & 201+ \\ 3 & 0 & 1 & 0\end{array}$


The geographical distribution and relative size of native coin finds are indicative of the fact that money use in pre-Majapahit Java was not universal. Indeed, it appears to have been restricted to two core areas. These are core Area I, corresponding roughly to central Java, and Core Area II, in eastern Java. (See map.) Core Area $I$ is the largest coin-using region and has produced the most varied of early Javanese coinages. Far fewer finds are reported from eastern Java (Core Area II). For example, silver finds average 109 coins per find in Core Area I as compared to only 60 coins per find in Core Area II, or just over one half as many. Simllarly, gold finds in Core Area I average 62 coins per find, while Core Area II averages only 36 coins per find. This points up a much more intensive use of preclous metal coinage in Core Area I as compared with Core Area II. Indeed, it is in Core Area II that Chinese copper cash comes to dominate and replace the earlier gold and silver coinages during the late thirteenth century.

An interesting feature of coin finds from early Java is that gold and sliver are generally not recovered together. The exceptions are from Core Area I-Semarang/Japara (Appendix C, nos. 2, 3, 4, 5), and to the east in Kedu (Append ix C, no. 1). This limited evidence suggests that, even within the two core areas, the circulation of gold differed considerably from the circulation of sllver. The notion of distinctive circulation patterns for silver and gold is supported as well by the geographical distribution of the various coin types.

Irregular stamped silver ingots, the precursor of Java's first true coinage, have been recovered in Banyumas (Appendix A, nos, 16, 17) and Pekalongan (Appendix $A$, no. 18), in the eastern part of Core Area I. Silver Sandalwood Flower coins, while widely distributed throughout both core areas, are concentrated in Core Area I. The two largest finds, 1512 specimens (Appendix A, no. 58) and 490 specimens (Appendix A, no. 20), are from Madiun and Kedu respectively. Further indication of Kedu as a coin-producing area is iliustrated by additional finds of 296 silver Sandaiwood Flower coins (Appendix A, no, 25) and 383 unspecified silver coins (Appendix $A$, no. 37). The only major silver coin find of Core Area II, some 353 specimens, is from Pasuruan (Appendix A, no. 63).

In contrast to sllver discoveries, gold Piloncito coins have been reported primarily to the west of Core Area I. The two largest finds, of 300 and 700 specimens of Piloncito Class A coins, were discovered in Preanger (Appendix B, nos. 1, 2). The 1 argest gold find in Core Area II consists of 135 Piloncito type coins from Malang (Appendix B, no. 22).

While the importance of coinage cannot be doubted, the precise role of coinage in the pre-Majapahit Javanese economy is unclear from the inscriptions and coinfinds alone. Foreign accounts of early Java, particularly the Chinese, clarify the exchange aspects. Both Ma Tuan-lin and the Sung-shih record that in Java (She-p'o):

They cut up leaves of silver to make coins for business purposes; one coin of which is exchanged by the government for 1 hu $2 t$ 'ou (approximately 12 bushels) of rice. 21

Writing in the early thirteenth century Chao Ju-kua describes the coinage of Su-ki-tan (Central Java).

21. Friedrich Hirth and W. W. Rockhill, Chau Ju-kua: His Work on the Chinese and Arab Trade in the Twelfth and Thirteenth Centuries, Entitled Chu-fan-chi (Taipei: Ch'eng-wen Publishing Company, 1970), p. 81, note 14; de Saint-Denys, Ethnographie des peuples etrangers, vol. 2, p. 496. 
The people [of Su-ki-tan] use as a medium of trade pieces of alloyed silver cut into bits like dice and bearing the seal of the Fan-kuan [foreign official] stamped upon it. Six of these counters are worth one tael of trade gold, and each one may be exchanged for from thirty or forty up to one hundred sheng (pecks) of rice. For al1 their other trading they use [this money] which is called 'She-p'o chin' [She-p'o gold] from which it may be seen that this country is [identical with] She-p'o. 22

The importance of Chao Ju-kua's statement is that it identifies two distinctive sorts of coinage, a silver coinage apparently used for local exchange, and a gold trade coinage. As mentioned above, archaeological discoveries confirm this bi-metallic situation in early Java. In addition, the mention of a foreign official in connection with trade is affirmed by the use of foreign tax collectors in pre-Majapahit Java. 23

Chao Ju-kua also provides insight into how officials in early Java were paid. Those who worked in positions similar to the Ministers of state in China, ". - have no monthly salaries, but at intervals are given a liberal supply of native produce," whereas "the commanders of the troops received an annual salary of twenty taels of gold, and the soldiers of the army, 30,000 in number, also receive fixed annual pay in gold in various amounts." 24 It is significant that the officials in more sedentary and secure positions receive their pay in perishable commodities, while the soldier, who must take his belongings with him into the field, is paid in gold.

Chao Ju-kua continues: "The people pay a tithe rent. . . They do not inflict corporal punishment and imprisonment on criminals; they arre fined an amount of gold varying according to the gravity of their crime, "25 The Sungshich adds, "only robbers and thieves are made to suffer death." 26

From these statements it is clear that by the thirteenth century monetization affected the areas of commercial, military, and fiscal administration. The populace still relied upon payments in kind to fulfill fiscal obligations. For further insight into the process of monetization, an examination of the actual coins and coin-like pieces recovered in Java is in order.

\section{A Typology of Early Javanese Silver}

The international currency of Indonesia during the Classical period (between approximately $A D 800$ and 1300 ) is a Sandalwood Flower coinage struck in silver, gold, and electrum. Typological variations within the series point to at least

22. Hirth and Rockhill, Chau Ju-kua, p. 82.

23. Jan Wisseman, "Markets and Trade in Pre-Majapahit Java," in Economic Exchange and Social Interaction in Southeast Asia: Perspectives from Prehistory, History and Ethnography, ed. Karl L. Hutterer (Ann Arbor: The University of Michigan Center for South and Southeast Asian Studies, 1977), Pp. 207-8.

24. Hirth and Rockhi11, Chau Ju-kua, p. 76.

25. Ibid., pp. 76-77.

26. Willem Pieter Groeneveldt, "Notes on the Malay Archipelago and Malacca, Compiled from Chinese Sources," Verhandelingen van het Bataviaasch Genootschap (henceforth VBG) 39 (1877): 1-44, see p. 16. 
three major areas of production: the west coast of Sumatra; 27 peninsular Thatland; 28 and central and eastern Java. The earliest coins in this group, from central Java, can be dated to the late eighth or early ninth century. At least one specimen of the type has been discovered outside southeast Asia. This is a

27. Classical period coinfinds from Sumatra are primarily gold Sandalwood Flower coins. See Henricus Christian Millies, Recherches sur les monnaies des indigenes de l'archipel Indien et de la peninsule Malaie (The Hague: Nijhoff, 1871) [hereafter Millies (1871)], pp. 65-67. John Miksic surveys the numismatic evidence in "Classical Archaeology in Sumatra," Indonesia 30 (1980): 43-66, particularly p. 61. He mistakenly identifies the coinfinds on Sumatra with the Piloncito coinage of Java and the Philippines. The only native coins reported from Sumatra are of the Sandalwood flower type. An uncertain number of silver coins have been reported but not confirmed. In 1904, for example, a find of 79 silver coins was made at Kru, Bengkulu. [Notulen van het Bataviaasch Genootschap (henceforth Not.) (1904), p. 36]. No description of these pieces is available.

Sandalwood Flower Class B (gold, electrum, and silver). The coins are struck on a regular flan with a diameter between 8.5 and $9.0 \mathrm{~mm}$, and possess a finely executed and relatively small Sandalwood Flower design similar to that found on the Malay Peninsula coins. (Wicks, "Survey of Coinage," Plate 20, coins 178180.) Traces of an unclear inscription, sometimes identified as pa, is visible on these pieces. Weights range from 0.72 to $0.91 \mathrm{gm}$. Millies noted a silver specimen from Barus weighing $0.15 \mathrm{gm}$ (p. 67). The majority of finds of this class, in gold or electrum, have been made near Barus on the west coast and Bengku1u in the southwest. [Millies (1871), Plate 15, nos. 128-130.]

Barus finds: $E$. Netscher, "Gouden hindoe-munt van Sumatra," Tijdschrift voor Indische Taal- Land- en Volkenkunde [henceforth Tijd.] 5 (1856), p. 485; Mil1ies (1871), pp. 65-67; Not. (1879), Pp. 109, 144; OV (1914), p. 114.

Rejang (Bengkulu) finds: Not. (1911), p. 91; oV (1914), p. 115. Recently, at least two gold Sandalwood Flower coins were found at Muara Jambi in a reliquary deposit. They are of an undetermined variety, but do have the finely executed four-petaled flower on the obverse. (E. Edwards Mckinnon, personal communication.) This is the first recorded find on the east coast of Sumatra. Perhaps one or two specimens are known from Java. [E. Netscher and Jacobus Anne van der Chijs, De Munten van Nederlandsch Indie (Batavia: Lange, 1863) [henceforth Netscher and van der Chijs (1863)], Plate 12, no. 120 and p. 131; Mil1ies (1871), Plate 1, no. 6.]

Sandalwood Flower Class $C$ (gold). At least one small gold coin, about $7 \mathrm{~mm}$ in diameter and weighing $0.26 \mathrm{gm}$, was al so recovered near Barus. [Mil11ies (1871), Plate 15, no. 130 and P. 65; Wicks, "Survey of Coinage," Plate 20, coin 181.] The inscription reads mā, similar to Class A colns. The Sandalwood Flower design is regular.

28. Sandalwood Flower coins from peninsular Thalland ( $C l$ ass $A$, gold and silver) are very finely made. (Reginald LeMay, The Coinage of Siam [Bangkok: The Siam Society, 1932], Plate 32, no. 8, for example.) The die engraver has drawn an incuse square which fills only about one-half of the avaliable space on the reverse of the coin. A small square in relief remains in the center of the coin. Four lozenge-shaped petals are drawn from the center to each corner of the incuse square. The stamp is slightly smaller and more finely executed than the main series from Java. The obverse contains the character ma. The style is regular; strokes are rounded off and of an even thickness throughout. There are no certain epigraphic affinities. Small hoards of silver class A coins from Nakhon Sri Thammarat were reported as early as the 1930s. (Le May, Coinage of Siam, p. 125.) Specimens are al so said to originate from Suratthani and 
silver coin recovered from Fustat, Egypt, in a ninth century context, further confirming its international character. 29 The end of the Sandalwood Flower tradition is signaled by the adoption of Chinese cash as a circulating medium by Majapahit sometime around 1300. Related to the Sandalwood Flower series, and perhaps its precursor, is a rare group of irregular stamped silver ingots.

Irregular Silver Pieces ( $f$ ig. I)

Millies considered a number of irregular cast silver pieces from central Java to represent the earliest form of Javanese metallic currency. 30 These slightly cup-shaped pleces of silver are impressed with two stamps: an incuse four-part petal design on the concave portion, similar to the Sandalwood Flower coins discussed below, and a vase form on the convex surface. Most were cut in half from a circular disk; others are clipped to an irregular square shape. 31 The majority have been found in the central part of Java. Identifiable finds are all within Core Area I and include Cirebon (Appendix A, no. 5), Banyumas (Appendix $A$, nos. $7,16,17$ ), and Pekalongan (Append ix $A$, no. 18).

The weights are irregular: $61.50 \mathrm{gm}, 42.44 \mathrm{gm}, 38,40 \mathrm{gm}, 28.25 \mathrm{gm}, 27.58 \mathrm{gm}$, $22.84 \mathrm{gm}, 19.80 \mathrm{gm}, 17.70 \mathrm{gm}, 17.58 \mathrm{gm}, 15.90 \mathrm{gm}, 15.76 \mathrm{gm} .32$ As al1 reported specimens are of extremely high value, these stamped ingots would doubtless have served as stores of wealth and not as a currency acceptable in the marketplace. There is no clear evidence that a denominated weight system is at work. This contrasts dramatically with the succeeding groups of coins.

\section{Silver Coinage}

Found throughout central and eastern Java is a silver Sandalwood Flower coinage. Early specimens are flat and thick. Later coins are broader with a noticeable convexity. The obverse of Sandalwood Flower coins contains the letter $m \bar{a}[=m \bar{a} a]$, while the reverse is impressed with an incuse square and a fourpetaled flower design identified as the Sandalwood flower, providing the name for

Songkh1a. (Coins in Thailand [Bangkok: Fine Arts Department, 1973], fig. 13. Henceforth (IT.) The recovery of a silver Class A specimen $(2.09 \mathrm{gm})$ from Fustat, Egypt, in a ninth century context, provides a secure dating for the series. (American Numismatic Society, New York.) The unusually light weight could indicate that the coin was struck to a lower standard than the ca. 2.4gm coins from Java. (Wicks, "Survey of Coinage," P1ate 20, coins 186, 187.) Gold and electrum specimens are quite common and come most notably from Satingphra, Nakhon Sri Thammarat, Suratthani, and Songkhia. [CIT (1973), fig. 13, P. 2I; Jean Boisselier, "Recherches archeologiques en Thalland," Arts Asiatiques 20 (1969): 47-98, see fig. 41 and p. 69.J The coins are 10.9 and $8.7 \mathrm{~mm}$ in diameter; there are no recorded weights.

29. American Numismatic Society, New York. Sandalwood Flower Class A. See note 28.

30. Millies (1871), p. 12.

31. Ibid., Plate I; W. F. Stutterheim, Kultuur Dfawa (Weltevreden: Java-Instituut dan G. Kolff, 1926), p. 44, fig. 56. The specimen published by Stutterheim is possibly of gold.

32. Specimens reported by Netscher and van der Chijs (1863); Millies (1871), and examined by the author. 

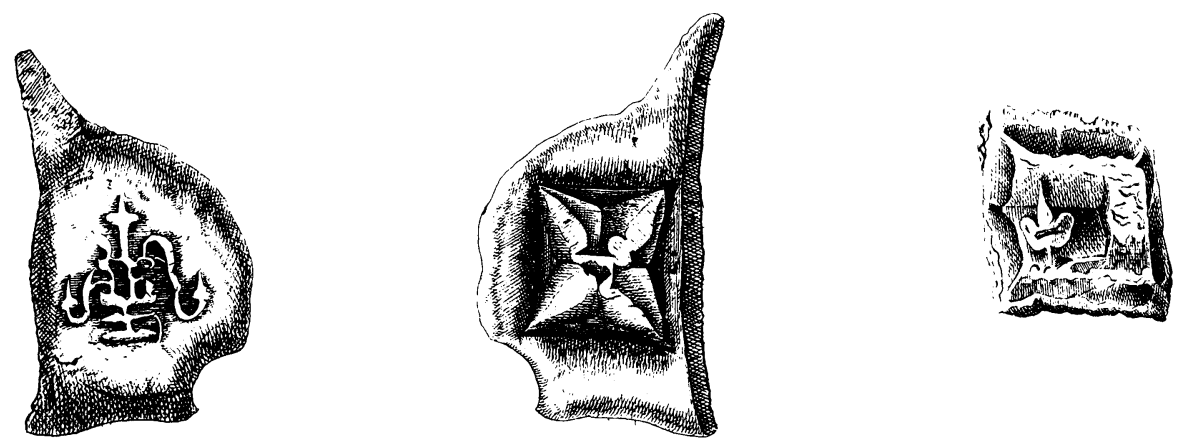

Fig. 1: Irregular Silver

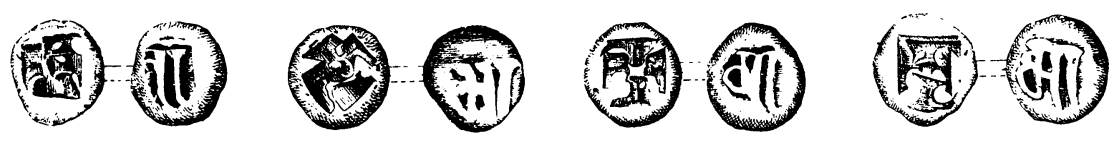

Fig. 2: Sandalwood Flower Class D (Silver)
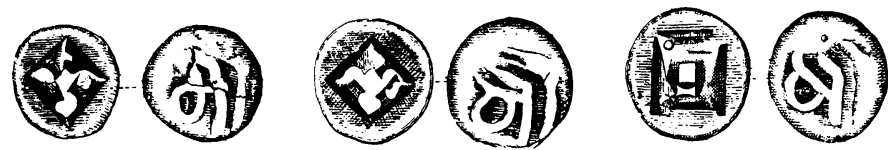

Fig. 3: Sandalwood Flower Class E (Silver) 
this series. Classes $A$ through $C$, mainly of gold and electrum, are from Sumatra and the Malay Peninsula. As discussed in the previous section, Sandalwood Flower coinfinds are known from Core Areas I and II, with finds from central Java predominating. (See Appendix.) A majority of finds reported only as "silver coins" are doubtless Sandalwood Flower pieces.

Class $D$ (silver) [fig. 2]. In this class a four-petaled flower with roughty executed petals is placed in an irregular square. 33 The flat $9-10 \mathrm{~mm}$ flan is somewhat thick and slightly irregular in shape. The silver is apparentiy pure. This, the earliest Sandalwood Flower colnage in Java, if not in all of Southeast Asia, is inscribed in Early Nāgari. Triangular headmarks are a noticeable feature of this writing style. The verticals are exaggerated, giving the letter a heightened effect. The lower ends of the vertical strokes taper to a point and curve slightly to the right.

The limited use of Early Nägari in Java would support an eighth or ninth century date for this group of Sandalwood Flower coins. There are only four stone inscriptions written in this style; all are from southern central Java and date to the fourth quarter of the eighth century. 34 Two dated inscriptions are from Kalasan ( $A D$ 788) and Kelurak (AD 782).

Weights are very regular for coins in this class, ranging from 2.3 to 2.5 grams. The majority of specimens weigh $2.4 \mathrm{gm}$ or 1 masa. The geographical distribution of this group is limited to Core Area $I$. Finds include Cirebon (Appendix $A$, no. 3 ), Banyumas (Appendix $A$, no. 16), in the eastern section of Core Area I, and Kedu, in the center of Core Area I (Appendix A, no. 25). A number of specimens display a cup-shaped flan, providing a transition to the following class. 35

Class $E$ (sllver) [fig. 3]. Class E constitutes the main group of Sandalwood Flower coins found in Java. ${ }^{\circ}$ The coins are considerably larger than Class $D$, with specimens $13-14 \mathrm{~mm}$ in diameter, struck on an irregular cup-shaped f1an. The flower motif is often mis-shapen. Weights are variable, ranging from 2.1 to 2.4gm. The calligraphic style of these coins differs considerabiy from the first group. Headmarks are no longer present. The strokes are all of roughly equal thickness, with no tapering. The main body of the letter connects in various ways with the horizontal and vertical members. These differences can be described as a miniscule $p$, d and signs. Millies points out that the open form the $m \bar{a}$ is found in inscriptions dating between the seventh and eleventh centuries. ${ }^{37}$ Identifiable finds of $\mathrm{Class} \mathrm{E}$ coins are from Banyumas (Appendix

33. Millies (1871), Plate I, nos. 13-19; Wicks, "Survey of Coinage," Plate 20, coins 192-194.

34. See J. G. de Casparis, Indonesian Palaeography (Leiden: Bri11, 1975), Plate 3 , a and pp. 35-37; F. D. K. Bosch in Tijd. 68 (1928): 57-62, Plate 2; F. D. K. Bosch, "De inscriptie van Keloerak," Tijd. 68 (1928): 1-56, Plate 1. L. C. Damais, "Les ecritures d'origine indienne en Indonésie et dans les sud-Est Asiatique continental," Bulletin de la Socleté des études Indochinoises de Saigon n.s. 30 (1955): 365-82, tables A-H, especially table E. Siddhamātrkā, eighth century.

35. MLV Collection.

36. Millies (1871), Plate I, nos, 20-22, 23 ( $1 / 2$ unit); Wicks, "Survey of Coinage," Plate 20 , coins 195-198.

37. Millies (1871), p. 16. Louis-Charles Damais, "Les ecritures d'origine indienne," table E, ca. 1290. 
A, nos. 9, 17), Kedu (Appendix A, no. 27), and Semarang (Appendix A, no. 48), all within Core Area I.

Class $F$ (silver). These are simjlar to Class $E$ except that the coins have a bubbly obverse surface texture. 38 Weights for large specimens are also similar to Class E coins, e.g., 2.2-2.4gm. A notable development is the adoption of three denominations:

$\begin{array}{lll}\mathrm{Cl} \text { ass } \mathrm{F} & 13-14 \mathrm{~mm} & 2.2-2.4 \mathrm{gm} \\ \mathrm{Cl} \text { ass } \mathrm{Fa} & 11-12 \mathrm{~mm} & 1.1-1.2 \mathrm{gm} \\ \mathrm{Cl} \text { ass } \mathrm{Fb} & 10-11 \mathrm{~mm} & 0.4-0.6 \mathrm{gm}\end{array}$

By weight, these divisions would represent the masa, 2 kupang and 1 kupang denominations. A hoard containing all three denominations was discovered near Yogyakarta in the 1920s. 39 The fact that the weight term kupang first appears in Javanese epigraphy during the eleventh century in port areas aids in dating class $F$ coins to the eleventh and twelfth centuries. It also suggests that the introduction of minor coin denominations into the Javanese economy is at least partially due to the influence of international trade.

Class $G$ (silver). Essentially similar to Class $E$, the obverse is marked by a semicircular row of beads to the right of the inscription. 40 The obverse graph is of the $p$ form with an exaggerated angle. Weights range from 1.8-2.3 grams, a noticeable downward shift from other classes. The silver is impure.

Class $H$ (copper). Similar to Class $E$, these coins are made of copper. ${ }^{41}$ Their weights are $10 \mathrm{w}(1.3$ and $1.8 \mathrm{gm}$ for recorded specimens) while the $13-14 \mathrm{~mm}$ diameter of a regular ma-coin is maintained.

\section{A Typology of Early Javanese Gold}

In Java and the Philippines a gold bullet-like coin circulated between the ninth and twelfth centuries. Modern Filipino scholars have labeled these pieces Piloncito cojns after the shape of unrefined sugar cones commoniy sold in the marketplace. 42 The greatest variety of coins in this group have been found in central and eastern Java; finds from peninsular Thailand are not unknown. ${ }^{43} \mathrm{~J}$ ava

38. FM Collection. Millies (1871), p. 15, notes that the 1.18-1.20gm denomination is extremely rare (Plate $I$, no. 23 ). He knew of only one $1 / 4$ unit coin.

39. FM Collection.

40. MLV Collection.

41. MLV Collection.

42. Javanese finds: William Marsden, Numismata Orientalia IUustrata (London: printed for the author, 1823-25), vol. 2, p. 811, no. MCCXLVII; Netscher and van der Chijs (1863), Plate 12, no. 119; M1llies (1871), Plate 1, nos. 1-5 and pp. 8-11; Wicks, "Survey of Coinage," Plate 20, coins 199-203.

Philippines finds: Not. (1888), p. 123; Angelita G. de Legarda, "Some Notes on the 'Piloncito," Barilla (October 1976): 192-98, see p. 194 for a specimen of Javanese origin found in the Philippines; idem, Piloncitos to Pesos (Manila: Bancom Development Corp., 1975), p. 14. A coin typology and additional bibllography can be found in Wicks, "Survey of Coinage," PP. 252-57 and Plate 21, coins 204-207.

43. CIT, fig. 14, p. 22 , center coin. 


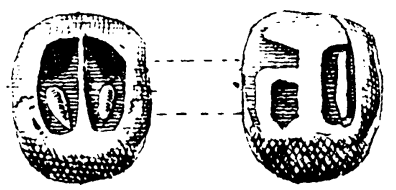

Fig. 4: Piloncito Class A (Gold) (enlarged)
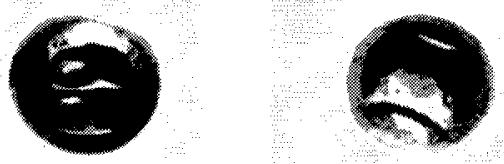

Fig. 5: Piloncito Class D (Gold)
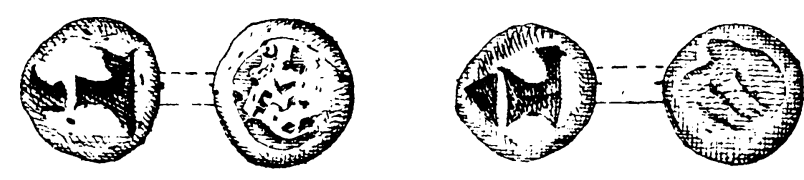

Fig. 6: Piloncito Class E (Gold) (enlarged) 
has also produced a group of irregularly shaped cut gold pieces impressed with designs similar to those found on Sandalwood Flower and Piloncito coins, and which are contemporary with the native gold coinages.

\section{Irregular Gold Pieces}

Finds of irregular gold are somewhat scarce in early Java. This is doubtless due, in part, to the greater intrinsic value of the gold as compared to silver, making it less 1 ikely that finds would be preserved and reported. One example of an irregular cast gold piece, cut from a larger ingot, weighs $39.57 \mathrm{gm} .44$ Other irregular gold pieces include small square sheets of cast gold, stamped with a vase design on both sides oriented either to the sides of the square or to its corners. A major find (Appendix $B$, no. 4) was made in 1904 in Sukapura. 45 Weights are $3.74 \mathrm{gm}, 3.67 \mathrm{gm}$, and $3.60 \mathrm{gm}$ for pieces $w$ ith the vase oriented to the corners $i_{6}$ a specimen with the vase oriented to the edge of the square weighs $5.01 \mathrm{gm} .46$

\section{Java's Early Gold Colnage}

The obverse of all Javanese Piloncito types consists of a rounded or angular square incuse with two beads (shaped like the seed of the sesamum plant) and a central 1 ine between them in relief. The line is wide at the bottom and tapers to a point. The two teardrop or oval beads touch the base of the 7 ine and point to the two outer angles of the incuse square. Millies' description of these pieces as "petites barres carrées oy des cubes d'or" immediately brings to mind the Arabic descriptions of Zābaj. 47

Class A (ggld) [fig. 4]. In Class A the incuse design produces a rounded coin profile. ${ }^{48}$ The reverse is inscribed with a single character, identified as ta. 49 Some specimens show traces of a long vowel. 50 Palaeographic considerations would date the initial appearance of the piloncito type to the late eighth or early ninth centuries. 5 The graph is well formed with an extremely wide headmark similar to the cross-section of an I-beam, known as nail-heads, giving the reverse profile of the coin a distinctly squared appearance. Recorded specimens weigh 1 masa: $2.3-2.5 \mathrm{gm}$. Findsites of this $7 \times 7 \times 5 \mathrm{~mm}$ coin include Semarang (Appendix B, no. 11, Appendix $C$, nos. 2, 3, 4, 5), Preanger (Appendix B, nos. 1, 2, 3), and Kedu (Appendix B, no. 10), a11 with in Core Area I. Related coins from Java are uninscribed but maintain the line-sesamum seed motif as a common obverse type.

44. MLV Collection.

45. MLV Collection.

46. MLV Collection.

47. Millies (1871), Pp. 20-23; for a recent translation and discussion of the relevant texts see Tibbetts, Study of the Arabic Texts, passim, and Wicks, "Survey of Coinage," PP. 214-18.

48. Millies (1871), Plate I, nos, 1-3; Wicks, "Survey of Coinage," Plate 20, coins 199-200.

49. Millies (1871), pp. 8-9.

50. ANS, BM Collections. Millies (1871), Plate 1, no. 1.

51. Millies (1871), Pp. 8-9. See note 34 above for references to palaeography. 
Class $B$ (gold). Similar to $C l$ ass $A$, coins in this group are more spherica1. 52 An irregular pattern, possibly a letter, is visible on the reverse. Only one specimen has been examined by the author; it was discovered in a major hoard at Sukapura in 1904, along with specimens of Piloncito Class $C$ and $D$ coins (Appendix B, no. 4). The coin is $8 \mathrm{~mm}$ in diameter and weighs $2.45 \mathrm{gm}$.

Class $C(g o l d)$. These coins are similar to $C l$ ass $B$, but have what might be described as parallel plier marks or grooves on the reverse. 53 Specimens of this class were found together with Class B and D Piloncito coins in the 1904 Sukapura find (Appendix B, no. 4). Specimens are $8 \mathrm{~mm}$ in diameter and weigh 2.4$2.5 \mathrm{gm}$ or 1 masa. Small specimens (Class $\mathrm{Ca}$ ) with a plain or irregular reverse are known. A $7 \mathrm{~mm}$ specimen weighs $1.18 \mathrm{gm}$ or 2 kupang. 54 Coins of 1 kupang weight $(0.60-0.63 \mathrm{gm})$ about $6 \mathrm{~mm}$ in diameter are also known ( $\mathrm{Cl}$ ass $\mathrm{Cb}$ ). 55

Class $D$ (gold alloy) [fig. 5]. Coins in this group have a cone-like profile, similar to the Piloncito types found in the Philippines. 56 The obverse is an incuse square, sometimes with rounded corners and a circular upper profile. The line-sesamum seed motif is present. On the reverse (the tip of the cone) are two opposing indented or inscribed curves following the surface of the cone. The lines are regular and intentional, differing greatly from the irregular grid and plier marks found on Class C coins. The gold is of a lighter color than other Piloncito types. Weights $(2.0-2.6 \mathrm{gm})$ and sizes $(6.5-8 \mathrm{~mm})$ are somewhat irregular as well. Coins of this group were found together with Class $B$ and $C$ Piloncito types in the 1904 Sukapura find (Appendix B, no. 4).

Class $E$ (gold) [fig. 6]. Another variant of the Piloncito type from Java is an almost flat coin. 57 The flan is formed from a spherical bead of gold which has been flattened to present a surface suitable for the impression of a design. The incuse portion takes on a triangular character. The sesamum seed "eyes" are placed in the middle of two opposite sides of the triangle. A line joins these two sides and is placed close to the angle, forming a smaller triangle of its own. The reverse is irregular and may show traces of a letter or grid pattern (from the anvil?). Specimens are about $7 \mathrm{~mm}$ in diameter and weigh approximately $1.2 \mathrm{gm}$ or 2 kupang. 58 They have been discovered in the vicinity of Borobudur in Kedu ${ }^{59}$ (Appendix $B$, no. 9).

Class $F(g o l d)$. An as-yet-unique specimen provides another variation on the Piloncito theme in Java. ${ }^{0}$ The spherical bead has also been slightly flattened, but the incuse square has an hour-glass or bowtie-like form with one side

52. MLV Collection. See CIT, fig. 14, middle, for a similar coin from the Malay Peninsula.

53. MLV Collection.

54. MLV Collection.

55. MLV Collection.

56. MLV Collection. Formerly Scott Semans Collection [henceforth SS]. Wicks, "Survey of Coinage," Plate 20, coin 201.

57. Millies (1871), Plate I, nos, 4-5; MLV Collection; Wicks, "Survey of Coinage," P1ate 20, coins 202, 203.

58. MLV Collection.

59. Millies (1871), p. 10.

60. Formerly SS Collection. 
slightly curved instead of angled. The beads and mid-line are diminished in size. The coin is $8 \mathrm{~mm}$ in diameter and weighs 1 masa, $2.42 \mathrm{gm}$.

A pattern which emerges from this coin typology is that the earl iest coinages of silver and gold are of a single high denominational unit--the masa of $2.4 \mathrm{gm}$. Subsequentiy, smaller coins are introduced, the $1.2 \mathrm{gm}$ two kupang and $0.6 \mathrm{gm}$ kupang. In addition, the earliest colns are of relatively pure gold or silver. Later classes of both Piloncito and Sandalwood Flower pieces employ increasing amounts of alloy, chiefly in the form of copper. This movement is probably due to larger quantities of Chinese cash being imported into Java, documented by the Chinese in the late twelfth century, and to decreasing local supplies of gold and silver, as well as being a response to the need for low-value coin denominations which would ultimately result in the wholesale adoption of chinese cash. The full impact of Chinese cash on the Javanese economy is considered in the following sections.

\section{Transition to the Fourteenth century}

Chinese cash came to dominate and replace the earlier gold and silver coinages about the year 1300. There is evidence, however, that chinese cash had played a role in the Javanese economy, both directly and indirectly, since at least the late twelfth century. Chao Ju-kua, writing in the early 1200s, noted that in order to derive more profits from the pepper trade with Java [She-p'o], Chinese merchants, ". . - are in the habit of smuggling [out of China] copper cash for bartering purposes." 61 It is unclear from this statement whether Chinese copper cash were valued by the Javanese as a commodity or currency; since barter is mentioned, the former is more likely. Further, by the late twelfth century, locally cast coins of copper, silver, and tin were introduced, presumably as a result of the presence of Chinese cash in Java. Although no specimens are known to have survived, they are first reported by the Chinese in 1178.62

It is notable that the latest 01d Javanese inscriptions with the traditional $m \bar{a}$, su, ku units are dated to $\$ 1216$ (AD 1294) and $\$ 1218$ (AD 1296).63 By 1350 we find the first notice in Javanese inscriptions of a pisis or picis, referring to Chinese copper cash currency. ${ }^{64}$ From this change of nomenclature it is evident that there was a major shift in the way goods were valued and fines calculated in the decades around the year 1300.

The most significant source signaling the adoption of Chinese coinage in late thirteenth century Java is a Majapahit copper-plate inscription of ca. 1350 . It was not uncommon in early Java for lawsuits to be brought over the rightful ownership of 1 and. In this instance the defendant argues that his parcel of 7 and was ". - property given as security by my great-great grandfather for one and

61. Hirth and Rockhi11, Chau Ju-kua, p. 78.

62. Ibid., PP. 78 and 81 n. 14 .

63. OJ0: 81, 195; R. Ng. Dr. Poerbatjaraka, "Oorkonde van Krtarajasa uit 1296 AD (Penanggoengan)," IN-I, I (1940): 33-49.

64. Theodore G. Th. Pigeaud, Java in the Fourteenth Century, 5 vols. [henceforth Java] (The Hague: Nijhoff, 1960-63), 1 [text]: 104-107; 3 [trans]ation]: 151-55. 
a half measures [unit not specified] of silver, at the time that this 1 and of Java did not possess the means of the pisis."65 pigeaud, the translator and editor of this inscription, notes that pisis refers to Chinese copper cash currency. 66 This source would seem to imply that the transition to a nonnative currency took place some time in the late thirteenth century, which is confirmed by the latest instances of the use of $m \bar{a}$, su, ku units being $\$ 1216$ (AD 1294) and S1218 (AD 1296) mentioned earlier.

Several 01d Javanese texts, such as the Astadasavyavahara, originally translated from the Sanskrit, convert Indian monetary values into those used in Java. 67 These texts provide additional support, although without the same chronological precision, for the monetary changes mentioned above. For example, an Indian text might give the amount of a fine or payment in terms of pana. The 01d Javanese version would retain that amount and also express it in the indigenous $m \bar{a}$, su, ku monetary nomenclature. In addition, there are instances where a large numerical unit, referring to pisis or Chinese cash, is appended to the 01d Javanese emendation. The monetary values recorded in the documents thus represent adaptation to changing economic conditions in early Java.

The adoption of Chinese cash in Java is also documented by nearly 150 coinfinds. 68 There is virtualiy no mixing of Sandalwood flower and Piloncito coinages with Chinese cash in these finds, indicating the changeover from indigenous coinage to Chinese cash was relatively rapid and extensive. 69 As can be seen in the accompanying maps (see above, p. 42), Chinese cash finds are concentrated in eastern Java; they include the site of Majapahit's capital, Trawulan. The earlier gold and silver coins are found primarily in central Java, with a lesser core area in the east. It is in the east that Chinese cash first came to dominate and then replace earlier gold and silver coinages. It should also be noted that cash finds have a much more extensive geographical distribution than either gold or silver, indicating more widespread acceptance. That the transition to Chinese cash was complete is well attested by indigenous sources and foreign accounts of fourteenth, fifteenth, and sixteenth century Java.

\section{Coin Use in Fourteenth-, Fifteenth-, and Sixteenth-Century J ava}

Foreign trade was exceedingly important in Majapahit Java. The Nägarakertägama (completed in 1365) relates a particularly vivid scene.

$[W]$ ithout interruption al1 peoples come from other countries, of a 11 sorts, so Jambudwipa (India), Camboja, China, Yawana (Annam),

65. Pigeaud, Java, 3: 154 .

66. Ibid.

67. See Frits Herman van Naerssen, "The Astadasavyavahāra in 01d Javanese" [translated by Else Madelon Hooykaas]. Journail of the Greater India Society 15, pt. 2 (1956), pp. 111-32, particularly pp. 119-20. This was originally published in Bijdragen tot Land- Taal- en Volkenkunde 100 (1941): 351-77.

68. Chinese coinfinds are listed in Appendix $D$.

69. In only one instance are local gold and silver coins found with Chinese cash. In 1878, 140 silver Sandalwood Flower coins and 4 Chinese cash pieces were discovered in a metal pot in East Java. (Appendix $A$, no. 68 and Appendix $D$, no. 47.) This find is discussed further below. 
aiso Champa, Karnataka (in South India) and so on, Goda (Gaur) and Syangka (Siam), that are their places of origin, taking their way in ships, joining merchants, crowded. . . . Tradespeople and merchants are in the marketplace filling it in crowds, all their wares in great variety. 70

Although the basic structure of ceremony and redistribution continued from earlier times, more and more gifts were made in Chinese cash instead of gold or sllver. The distribution of precious textiles continued. The chapter on Räjapatnī in the Nägarakertagama, records an example of redistribution:

Utterly wonderful was the majesty of the Royal ceremony, the extreme end of the highest summit to the utmost. For, on seven days without interruption, money, clothes with food, unmeasured were distributed generally to the honoured caturashrame (four hermitages), and especlally to the honoured priests. . . 71

Revenues were figures in terms of Chinese cash. Fines, fees, and dues were computed likewise. Several contemporary documents illustrate these points. The Ferry Charter of $\$ 1280$ (AD 1358) reads, in part:

Now, because of the magnitude of the great happiness of the ferry men of all districts of the Island of Java . . . they now produce a festival-tax: every gift in cash that goes with their flower-offerings while respectfully making the anjali-salutation for the honored Holy Charter of the Lord's Order is 400 (copper cash) each, paid every full moon of Asādhā (June-July). . . 72

A simflar festival-duty is described in the Bililluk Charter of $\$ 1288$ (AD
1366 ).

The Charter of Karang Bogem (AD 1387) introduces the practice of using Chinese cash, not only as a medium of exchange, but also as a standard weight or measure.

Now there is a kawula (bondman) of mine from Gresik, a fisherman, who has a debt of exactly 120,000 (cash). As well as he can he takes assistants, fisherman. Now they can be free from the claim of Sidayu, but they have to meet the claim from the Interior. At GTangan Kawolu they shall bring in acan (fish preserve) weighing one thousand (cash) for each holder of tambak (fish-pond). The rest of the produce shall be brought to us. 74

Majapahit law-texts add details about ideal administration and incidentally about financial management. The Kutaramanawa, mentioned in the Trawulan inscription of $A D$ 1358, specifies that,

70. Pigeaud, Java, 3: 98, Canto 83 , stanzas 4 and 5.

71. Ibid., p. 77, Canto 66, stanza 3. See a7so ibid., p. 76, Canto 65, stanza 4.

72. Ibid., p. 160, Plate 9, recto.

73. Ibid., p. 166, recto.

74. Ibid., p. 173, recto. See also his commentary on vol. 2, p. 150. "The meaning of bobot sewu is: weighing as much as one thousand cash. The Chinese coins were used as money as well as for standard weight and even sometimes for standard measure." 
Children below ten years should not be tried for their offenses; the ampunt of the fine should not exceed 160,000 coppers (cash). - .

The section on thievery can be directly compared with the statement of Chao Jukua given above.

If a thief is caught in the act, he deserves a death sentence. . . . However, if he appeals to the king to save his life, he has to pay eight thousand (cash) for his life, twenty thousand (cash) for fine, and to return the stolen goods twice its value. 76

Other sections detail the fines for hunting in prohibited areas, for pawning 7 and to two different persons, and on money lending. ("Before going to a moneylender and signing an agreement one is advised to take a bath first, to have a clear and fresh sight." 77 In each case, the fines and fees are computed in terms of Chinese cash.

Fifteenth and sixteenth century accounts of Java emphasize the pervasiveness of Chinese copper cash in Majapahit. The Ying-yai Sheng-lan of Ma Huan, a Chinese Moslem interpreter who accompanied Cheng Ho on his great maritime expeditions during the early fifteenth century, states very simply, "Copper coins of the successive dynasties are in current use universal7y." 78 Tome Pires, writing almost a century later (ca. 1512-15), notes that on sunda, an island just to the west of Java, "For small money [they use] cash from China. They are pierced through the middle like ceitis so that they can be threaded in hundreds." He goes on, in a later section of his work, to say:

The coins of Java are cash from China... for a thousand they give you thirty less [in exchange], for that is the custom of the country. They take these thirty as dues for the lord of the place; and all trade is done with these [coins]. . . "80

Tome Pires also reports that dues of 4 percent were levied on all produce brought into Java:

The chief dues customarily paid in Java on the merchandise that goes there by sea are the anchorage dues; and for these a present is made, and they pay four hundred cash out of every ten thousand on the merchandise which is sold in the country. 81

The use of Chinese coins as weights, for administrative and commercial purposes, testifies to their importance in Majapahit. The pervasiveness of Chinese

75. S1ametmuljana, A Story of Majapahit (Singapore: Singapore University Press, 1976) [henceforth Majapahit], p. 169.

76. Ibid., p. 162, paragraphs 55 and 56.

77. Ibid., p. 162, paragraph 117. See a7so paragraphs 118, 122, 128, and 129.

78. J. V. G. Mills, Ying-yai Sheng-lan: The Overall Survey of the Ocean's Shores [1433] (Cambridge: Cambridge University Press, 1970), p. 88.

79. Armando Cortesaz, Suma Oriental of Tome Pires (London: Hakluyt Society, 1944), vol. 1, p. 170 .

80. Ibid., p. 181 .

81. Ibid., Pp. $181-82$. 
cash is also reflected in the Majapahit terracotta "piggybank."82 These banks have been recovered from many sites, but especially from Trawulan, Majapahit's capital. They are often found with Chinese cash still remaining inside them. The banks appear in many forms. Some are simple, consisting of a spherical hollow with a simple slit at the top. Others are more ornate and take on the appearance of a flowing vase, a boar, pig, ram, turtle, or even a human figure possibly representing the god of wealth.

There are indications of more widespread cultural change than the adoption of a new exchange medium. Particularly noteworthy is the fact that finds of Chinese copper cash and finds of gold and silver occur in very different contexts. (See Appendix.) Typically, gold and silver finds are buried with earthenware or porcelain vessels in association with precious metal jewelry. Almost without exception Chinese cash finds are in metal containers, commoniy of copper; earthenware or stoneware vessels feature only rarely. Further, associated articles are commonly made of bronze. These differences would indicate that apart from the movement toward a more fully monetized economy, other fundamental changes were taking place in trading patterns and the selection of prestige goods from pre-Majapahit to Majapahit times.

\section{Conclusion}

i

The transition from a gold and silver coinage to chinese cash in fourteenth century Java points up the growing need for a convenient exchange medium-such as Chinese cash--acceptable at sev $r 17$ vels of economic exchange and obligation, and the inadequacy of the avaliable media of exchange--silver and gold coinage--designed for high value, ritualized transactions. Further, the adoption of Chinese cash by the Javanese is clear evidence of the futility of Chinese efforts to stem the flow of cash into Southeast Asia. 83

Kenneth R. Hall has argued that Majapahit's adoption of Chinese cash was a result of the increasing role played by Java as a major international trading center during the thirteenth and fourteenth centuries. ${ }^{84}$ Pigeaud has suggested that the changeover came about as a result of the Mongol invasion of Java in 1293.85 The evidence presented here suggests, along with Hal1, that the monetization of the Javanese economy was a process extending over several centuries. Ritualized transactions were monetized as early as the eighth or ninth century, coinciding with the appearance of gold and silver coinage. The impact of chinese cash was felt only during the twelfth and subsequent centurles. And even before

82. See H. R. A. Muller, Javanese Terracottas: Terra Incognita (Lochem: Tijdstroom, 1978), pp. 27-31.

83. For a discussion of Chinese attempts to 1 imit the flow of cash into Southeast Asia, see Hirth and Rockhil7, Chau Ju-kua, Pp. 81-82, n. 16.

84. Kenneth R. Hal1, Maritime Trade and State Development in Early Southeast Asia (Honolulu: University of Hawali Press, 1985), p. 245. Additional references to Chinese cash in Majapahit Java have been gathered by Brian E. Colless, "Majapahit Revisited: External Evidence on the Geography and Ethnology of East Java in the Majapahit Period," Journal of the Malaysian Branch of the Royal Asiatic Society 48, 2 (1975): 124-61.

85. Pigeaud, Java, 4: 499. 
adopting Chinese cash unreservediy in the late thirteenth century, efforts were made to introduce low denomination coins. However that may be, the Chinese invasion of 1293 could well have provided the necessary catalyst for the immediate and complete shift to a Chinese cash medium of exchange, brought about by the sudden decrease (due to plunder?) of local supplies of gold and silver and a massive increase in the amount of avallable cash (brought by the invading Chinese). 86

ii

Coinage and markets are often thought to be interrelated. Karl Polanyl, for example, would go so far as to declare that market exchange could not exist without coinage. 87 More recent research has shown that this extreme view is only partially correct. Based on one well-documented example from Iron Age Europe, J. R. Collis holds that ". . gold and sllver coinage... had a prestige value, being employed in conditions of reciprocity, and bronze coinage was employed for market exchange." 88 Colin Renfrew has added that ". . . the existence of any low-denomination coinage, used within the jurisdiction of the issuing authority, is an indication of market exchange." 89 It is appropriate to compare these models to the situation in early Java.

By the ninth century, the same period which saw the development of an indigenous gold and silver coinage on the island of Java and elsewhere in the archipelag8, references to markets make their first appearance in Indonesian epigraphy. 90 Unfortunately it is not known precisely how the markets were monetized. The large unit gold and silver coins recovered archaeologically are not suitable for small-scale purchases. It is probable that rice, or some other uniform commodity, served as a medium of exchange in the local marketplace. 91 While the ritual and redistributive functions are emphasized in available sources, gold and silver coinage would also have functioned in international trade, as described by Chao Ju-kua in the early thirteenth century. It is only when Chinese cash came to be used for monetary purposes (rather than being seen primarlly as a commodity) that coinage could function at virtually all levels of the Javanese economy, for both commercial and administrative purposes, ultimately allowing for the full development of the Javanese market system.

The Javanese case points up the need to exercise caution when applying the Polanyi, Collis, or Renfrew models to archaeological data. First, Collis implies

86. Ibid.

87. Colin Renfrew, "Trade as Action at a Distance: Questions of Integration and Communication," in Ancient Civilization and Trade, ed. Jeremy A. Sabioff and C. C. Lamberg-Karlovsky (Albuquerque: University of New Mexico Press, 1975), p. 53.

88. J. R. Collis, "Markets and Money," in The Iron Age and Its Hill-Forts, ed. D. Hill and M. Jesson (Southampton, England: Southampton University Archaeological Society, 1971); Renfrew, "Trade as Action," p. 53.

89. Renfrew, "Trade as Action," p. 53.

90. J. Wisseman, "References to Merchants and Markets in Early Indonesian Epigraphy," in Ancient Civilization and Trade, ed. Sabloff and Lamberg-Karlovsky, pp. 266-72; and "Markets and Trade in Pre-Majapahit Java," in Economic Exchange and Social Interaction in Southeast Asia: Perspectives from Prehistory. History and Ethnography (Ann Arbor: University of Michigan, 1978), pp. 197-212.

91. Christie, "Patterns of Trade," p. 146. 
that precious metal coinage would be utilized only for redistributive purposes. In Java, the primary function of gold and silver coinage was redistributive; however, an important secondary role was their use in international commerce, implying at least some market basis. Second, Collis and Renfrew view base metal coinage as a distinctive sign of the presence of markets. Chinese cash in Java was at first seen primarily as a commodity, to be traded 1 ike any other form of goods. It was only later that the base metal coinage acquired the potential of being utilized in virtually all economic transactions. It is here that the qualifying phrase adopted by Renfrew ("used within the jurisdiction of the issuing authority") takes on particular force. When a base metal coinage circulates in the area intended for its distribution and use, a market orientation is likely, if not assured. Once it no longer becomes possible for the issuing authority to exercise jurisdiction, as when Chinese cash is exported to foreign countries, there is no guarantee that the primary function with in the reciplent society $w i 11$ be to facilitate economic exchange. Indeed, in many societles imported goods become markets of status and wealth. ${ }^{92}$ It cannot be assumed a priori, then, that the presence of base-metal coinage presupposes the presence of markets.

The above discussion serves to point out that while the general models provided by Collis, Renfrew, and Polanyi are suggestive of how particular patterns of economic behavior (redistribution and market exchange) might be identified from material remains, they cannot be applied without qualification. This is particularly true when coinage is imported rather than produced locally. In such instances one must search for signs of non-market usage (a source of metal for tools or utensils, for decoration or ornament) in an effort to determine more accurately the precise role of coinage within that society.

92. See, for example, Karl Polanyi, "Traders and Trade," in Ancient Civilization and Trade, ed. Sabloff and Lamberg-Karlovsky, Pp. 136-38. 


\section{APPENDICES}

\section{A PRELIMINARY LISTING OF JAVANESE COIN FINDS FROM DUTCH SOURCES}

This is a preliminary survey of coinfinds on the island of Java as reported in Dutch sources. It is divided into four sections: $A$. Silver Finds, B. Gold Finds, C. Mixed Gold and Silver Finds, and D. Finds of Chinese Copper Cash and Native Issues. Some terms used in the nineteenth century reports, such as boeddhamunt, are of uncerta in significance. A number of terms presumably refer to the Javanese temple token, modeled on the Chinese cash form, but having for its design Wayang figures. 93 These include gobog, and occasionally dagob, "amuletpenning" and "tempelmunt." Coins described as "Balische munten" are possibly of a similar nature. Kepeng refers to base metal coins, usually in tin, of local manufacture.

The original spellings of placenames during the period of Dutch administration are maintained; names in brackets indicate earlier equivalencles. Descriptions are based on information provided in the archaeological reports. Arrangement within each section is roughly west to east. To facilitate identification, each find is numbered. Finds specifically identified in the reports are so indicated, e.g., ma-coins. Uncertain finds are noted with a query, e.g., silver (?). Whenever possible the finds are clariffed with identifications in brackets [ ] which refer to the classification scheme adopted in this paper. Due to the lack of precision in the reports, in many instances it has not been possible to provide more than provisional identifications. Use of the phrase "reference is to" indicates that the description of a particular find does not correspond to the numismatic reference provided in the archaeological reports. Most recent references to a given find are 1 isted first; earlier notices follow.

Table of Abbreviations for Appendices

Millies (1871) Henricus Christian Millies, Recherches sur les monnaies des indigenes de l'archipel Indien et de la peninsule Malaie (The Hague: Nijhoff, 1871)

Netscher and van der Chijs

Not.

OJM

OV

Tijd.

van der Chijs (1896)
E. Netscher and Jacobus Anne van der Chijs, De Munten van Indie (Batavia: Lange, 1863)

Notulen van het Bataviaasch Genootschap

Oudheidkundig Onderzoek op Java en Madoera

Oudheidkundig Verslag

Tijdschrift voor Indische Taal- Land- en Volkenkunde

J. A. van der Chijs, Catalogus der Numismatische Verzamerling van het Bataviaasch Genootschap van Kunsten en wetenschappen, vierde druk (Batavia: Albrecht \& Rusche, 1896).

93. Javanese temple tokens are 111 ustrated by Millies (1871), Netscher and van der Chifs (1863) and Sir Stamford Raffles, History of Java, 3 vols. (London, 1817, 1830; Singapore: Oxford in Asia Historical Reprints, 1965). See also Anker Rentse, "Majapahit Amulets in Kelantan," Journal of the Malaysian Branch of the Royal Asiatic Society 14, 3 (1936): 302-4. Joe Cribb is preparing a comprehensive study of this series. 
APPENDIX A: SILVER FINDS

West of Core Area $I$

1. (Pagelaran, Soekanegara, Tjiandjoer). Various gold rings and silver $m \bar{a}-$ coins were found in a rice-field. [Sandalwood Flower type.] oV (1938), p. 17.

2. (Tjibodas, Tjimalaka [Tj jbeureum], Soemedang, Preanger). In a glazed brown pot, a large quantity of silver (?) coins were found. OJM (1914), p. 66; Not. (1909), pp. 23 and 38 .

\section{Core Area I}

3. (Tjirabak, Tjiawigebang [Lebakwangi], Tjirebon). Gold rings and earjewels and silver coins found in the grassy area of the Pasir Goenoeng Pandan. Coins same as Netscher and van der Chijs, Plate XIII, no. 126. [Sandalwood Flower Class D.] According to a report by van der Chijs, at the time this represented the westernmost extension of Hindu coin finds in Java. OJM (1914), p. 90 ; Not. (1897), p. 68.

4. (Goenoengkaroeng, Koeningan, Tjirebon). 100 silver "Hindu muntjes" found buried in the ground. Not. (1892), p. 56.

5. (Pasir-poetih, Koeningan, Tjirebon, Tjirebon). Four gold rings, three links of a golden chain, and some 60 silver coins in three pottery jars found in the ground. Said to be similar to find from Banjoemas described in Tijd. v01. II, part V. [Irregular silver.] OJM (1914), p. 87; Tijd. V (1856), p. 150.

6. (Poerwakerta [Koelon], Poerwakerta, Poerwakerta, Banjoemas). An earthen pot containing a gold ring and three silver coins. OJM (1914), P. 110; Tijd. XI (1862), p. 409.

7. (Kertanagara, Poerbalingga, Banjoemas). In an earthen pot in the ground, 120 silver (?) coins, six gold rings and a gold hook. [Irregular silver.] OJM (1914), p. 115; Tijd. II (1854), p. V-VII; Millies (1871), p. 14,

8. (Wanoegara, Tjahjana, Poerbalingga, Banjoemas). An earthenware pot containing a silver armring and 36 silver (?) coins. 0JM (1914), Pp. 115-16; Not. (1888), p. 40 .

9. (Paninis, Tjahjana, Poerbalingga, Banjoemas). 20 silver coins with five pieces of silver and a gold ring were found in the ground. Same as Netscher and van der Chijs, no. 125. [Sandalwood Flower Class E.] 0JM (1914), p. 116; Not. (1898), p. 112 sq.

10. (Sered, Singamerta, Bandjarnegara, Banjoemas). 104 gold and silver articles, found in the ground, among which were three silver coins. OJM (1914), p. 118; Not. (1877), p. 108.

11. (Dagan, Singamerta, Bandjarnegara, Banjoemas). A large hoard of material which included two silver coins in an earthenware pot. Described in Not. (1870), p. 51 as "boeddhamunten." OJM (1914), p. 120; Not. (1870), pp. 51, 72.

12. (Patoegoeran, Bandjar, Bandjarnegara, Banjoemas). Five gold rings, five gold ear ornaments and 120 silver coins (tjoeki perak), found in the ground. OJM (1914), p. 121; Not. (1880), p. 58 sq.

13. (Lemahdjaja, Bandjar, Bandjarnegara, Banjoemas). Six gold rings, two gold plates and seven silver coins. Described in Not. (1870), p. 79 as "boeddhamunt." OJM (1914), p. 122; Not. (1870), p. 79. 
14. (Samoedra, Pegadingan, Tjilatjap, Banjoemas). A tempafan with 67 silver coins was found near the village. OJM (1914), p. 127; Not. (1891), p. 2.

15. (Tjisoemoer, Poerwokerto, Banjoemas). Near a pond was discovered a stoneware pot from Kwangsi or Northern Tongking (9th century), wherein were found a number of gold rings set with stones, one gold earring, one silver ring with an inscription in Kadiri characters and 58 silver ma-coins. [Sandalwood Flower type.] ov (1930), p. 21.

16. (Banjoemas Residency). An earthenware pot with five silver coins. Identified with (1) van der Chijs (1896), p. 67, nos. 14, 16, and 23 ; (2) Millies (1871), nos. 12 and 11 [Irregular silver]; (3) Netscher and van der Chijs, nos. 123 [Irregular silver], and 126 [Sandalwood Flower Class D]. OJM (1914), P. 128; Tijd. IV (1855), p. 107 sq.; Not. (1862), p. 162; Not. (1864), p. 239; Not. (1879), p. 103; Not. (1891), p. 9.

17. (Banjoemas Residency). A find of 68 small and nine 1 arge silver "Hindoemunten." Identified as Netscher and van der Chijs, nos. 121, 122, 124 [Irregular silver] and 125 [Sandalwood Flower Class E]. Not. 17 (1879), pp. 154-55.

18. (Pekalongan Residency). In an urn were found silver coins and "lontarhandschriften." Identifled as van der Chijs (1896), p. 67 sq. nos. 5, 7 [Piloncito Class E], 16, 18. Same as Netscher and van der Chijs, nos. 131 [?], 124, and Millies (1871), no. 11 [Irregular silver].

19. (Slarang, Slawi, Tegal, Pekalongan). Find of 39 silver coins. OJM (1914), p. 142.

20. (Andongsili, Garoeng, Wanasaba, Kedoe). Find of 490 silver coins. OJM (1914), pp. 332-33; Not. (1904), pp. 23 sq. and 47.

21. (Windoesari, Garoeng, Wanasaba, Kedoe). One silver coin. OJM (1914), p. 330 .

22. (Wanasaba, Wanasaba, Kedoe). Find of silver coins. See Millies (1871), p. 14. OJM (1914), p. 330.

23. (Terwatang, Poerwadadi, Poerwaredja, Kedoe). Nine small gold rings and three gold eardrops and two silver coins were found in an earthenware pot. OJM $(1914)$, p. 316.

24. (Former Kedoe Residency). A silver coin. Van der Chijs (1896), p. 67, no. 7; identified as same as Millies (1871), nos. 4, 5. [Reference is to gold Piloncito Class E.] OJM (1914), P. 305.

25. (Taloen, Kedoe). 296 silver "button" coins found in an earthenware pot in a field. [Sandalwood Flower Class D.] OJM (1914), p. 305; Not. (1909), p. 167.

26. (Wagmin, Desa Getos, Kaloran, Temanggoeng, Kedoe). Find of 30 silver $m \bar{a}$-coins. [Sandalwood Flower type.] Not. 44 (1906), Pp. 32 and 49.

27. (Tjarikan, Tjandirata, Temanggoeng, Kedoe). Two gold ear ornaments and 58 dish-shaped silver má-coins found in the ground. [Sandalwood Flower Class E.] OJM (1914), p. 302; Not. (1899), pp. 177 and 228.

28. (Boresan, Kedoe). 14 gold rings, 46 silver coins found in an earthenware pot. OJM (1914), p. 304; Not. (1859), p. 36.

29. (Loew ihan, Sapoeran, Wanasaba, Kedoe). Ten silver (?) coins. OJM (1914), p. 349; Not. (1912), p. 81 sq. 
30. (Tegalamba, Sapoeran, Wanasaba, Kedoe). One gold ring and 150 silver coins found in the hamlet Pleregan. OJM (1914), pp. 349-50; Not. (1915), p. 36.

31. (Glapan, Sapoeran, Wanasaba, Kedoe). A gold ring with the inscription Sri and 40 silver coins found in the ground. OJM (1914), p. 351; Not. (1905), pp. 62 and 74; Not. (1906), pp. 32 sq. and 50.

32. (Sapoeran, Wanasaba [Ledok], Kedoe [Bagelen]). Find of 285 silver coins. Called "boeddha-muntjes." OJM (1914), p. 352; Not. (1865), pp. 132 and 156; Not. (1866), p. 256.

33. (Former Bagelen Residency, Kedoe). Silver coins. OJM (1914), p. 357.

34. (Goemawang [Kidoel], Leksana, Wanasaba, Kedoe). Find of 120 silver mäcoins in the hamlet Boengkoesan. [Sandalwood Flower type.] OJM (1914), p. 346; Not. (1912), pp. 54 and 62 sq.

35. (Former Afdeeling Ambal, Kedoe). Gold earring and a number of "Hindoemuntjes." OJM (1914), p. 324; Not. (1863), p. 307; Not. (1864), p. 315.

36. (Sadang, Al than, Keboemen, Kedoe). Two gold ankle rings, one finger ring and five silver coins found in the village. OJM (1914), p. 319.

37. (Karang Endep, Alihan, Keboemen, Kedoe [Bagelen]). Six gold rings, two gold armbands, six gold bells and 383 silver coins. OJM (1914), p. 319; Not. (1866), p. 256 .

38. (Moentoek Kedawoeng, Rawakele, Keboemen, Kedoe). 50 silver coins of various sizes found in an earthenware pot with eight "animal" coins. OJM (1914), p. 322; Not. (1912), p. 95; Not. (1913), p. 3.

39. (Perbata, Sapoeran, Wanasaba, Kedoe). 34 silver coins of silver with copper alloy. OJM (1914), p. 348; Not. (1865), pp. 35 and 91.

40. (Soekal1la, Garoeng, Wanasaba, Kedoe). Find of 35 silver mä-coins. [Sandalwood Flower type.] OJM (1914), p. 336; Not. (1909), p. 78.

41. (Sidamoelja, Parakan, Temanggoeng, Kedoe). Two silver rings and 15 silver mä-coins found underground. [Sandalwood Flower type.] OJM (1914), p. 297; Not. (1913), p. 112.

42. (Geling, Tajoe, Pati [Djawana], Semarang [Japara]). Find of one silver coin. OJM (1914), P. 203; Tijd. VII (1858), Pp. 187 and 246.

43. (Toeka, Grobogan, Grobogan, Semarang). Three pairs of gold ear bells, one pair gold ear drops, one gold ring and two silver ma-coins in an earthenware pot found in the ground. [Sandalwood Flower type.] OJM (1914), p. 197; Not. (1912), pp. 60 sq. and 73 .

44. (Siwalan, Kallwoengoe, Kendal, Semarang). Gold ring with an inscription, in a kind of Nägari, one small silver ring, another gold ring and five sliver coins found together. OJM (1914), p. 191; Not. (1869), p. 53.

45. (Kemasan, Oengaran, Salatiga, Semarang). A stone urn, with earthenware "scholteltjes" and two silver coins. OJM (1914), p. 178; Not. (1866), p. 242.

46. (Getas, Salatiga, Salatiga, Semarang). Ten gold rings and a number of silver coins. OJM (1914), p. 182; Tijd. $V$ (1856), p. 314; Not. (1875), Pp. 98 and 128.

47. (Kramat, Padoeroengan [Srondo], Semarang, Semarang). Three finger rings and eleven silver (?) coins found in the ground. OJM (1914), p. 168; Not. (1868), p. 36 . 
48. (Doeren, Tengaran, Semarang). In an earthenware pot with metal cover, were found gold rings and 96 silver dish-shaped ma-coins $13 \mathrm{~mm}$ in diameter. [Sandalwood Flower Class E.] OV (1939), p. 22; Jaarboek (1940) VII, p. 85.

49. (Former Afdeeling Djoeana, Semarang [Japara]). Earthenware pot with silver coins and other objects. OJM (1914), p. 204; Not. (1874), pp. 80 sq. and 92.

50. (Logandoe, Karanganjar). 27 anklerings of silver and bronze, three gold ear ornaments, 16 fragments of a silver basin or bowl and 442 ma-coins. [Sandalwood Flower type.] oV (1937), p. 23.

51. (Temanggoeng, Djoemeneng, Mataram, Jogjakarta). One gold seal ring, a silver coin, at the foot of the Merapi, and a Madjapahit-kris. OJM (1915), p. 14.

52. (Moedjamoedjoe, Kotagede, Mataram, Jogjakarta). A gold naga-head, breech-block (?), an armband, and two silver coins. OJM (1915), p. 11; Not. (1904), p. 52.

53. (Pesantren, Krapjak, Mataram, Jogjakarta). Ten gold and 26 silver armbands along with 186 pieces of silver coins ("muntstukken"). OJM (1915), p. 910; Not. (1893), p. 127.

54. (Jogjakarta, Jogjakarta, Mataram, Jogjakarta). Three gold rings, four pieces of gold and one necklace and 34 silver coins. OJM (1915), p. 9.

\section{East of Core Area I}

55. (Kedak, Modjo, Kediri). In an earthenware pot, earring, gold neck 7 ace and silver mā-coins. [Sandalwood Flower type.] ov (1938), p. 22.

56. (Gondek, Garanggareng, Magetan, Madioen). Three silver coins. OJM (1915), p. 125; Not. (1895), p. 15 .

57. (Mendak, Poeloeng, Panaraga, Madioen). 306 silver coins found in the ground. OJM (1915), p. 132; Not. (1878), p. 17.

58. (Biting, Poeloeng, Panaranga, Madioen). 1512 silver coins and three pairs of sliver armbands, in an earthenware pot found in the ground. OJM (1915), p. 134; Not. (1891), pp. 32, 45 .

Core Area II

59. (Malang, Pasoeroean). Find of six silver 01d Javanese coins. OJM (1923), p. 76 .

60. (Soekaredja, Gondanglegi, Malang, Pasoeroean). Find of two ma-coins. [Sandalwood Flower type.] OJM (1923), p. 61; Not. (1920), p. 334 sq.

61. (Sekaran, Gondanglegi, Malang, Pasoeroean). Find of eight mā-coins. [Sandaiwood Flower type.] Not. (1910), p. 106.

62. (Toempang, Pakis, Malang, Pasoeroean). Find of elght silver coins. OJM (1923), Pp. 61-62.

63. (Pamotan, Toeran, Malang, Pasoeroean). Find of 353 silver coins. 0JM (1923), p. 56; Not. (1912), p. 61 .

64. (Soemberkembang, Perceel, Toeran, Malang). Find of nine gold ornaments, including armbands, rings, earrings, along with 15 silver māa-coins. [Sandalwood Flower type.] oV (1937), p. 30. 
65. (Ampelgading, Toeren, Malang). In a tegalan was found a small bronze box, within which were a quantity of gold and silver ornaments and one silver má-coin. [Sandalwood Flower type.] ov (1939), p. 24.

66. ( $T$ jandi Songgoriti, Poedjon, Malang). In the ground near the foundation of the temple, four cubical stone boxes were found containing plates with the names of Hindu gods inscribed upon them (Brahma, Rudra, Uma, Durga) in a script of the 9th century, and inside them were four ma-coins. [Sandaiwood Flower type.] oV (1938), p. 23.

67. (Senggoeroeh, Wadoeng, Pakisadji, Malang). Photographs of silver mācoins. [Sandalwood Flower type.] oV (1920), p. 40.

East of Core Area II

68. (Soetja, Tamanan, Bondowoso, Besoeki). In 1878, along with a metal pot and pan, 140 silver "Hindu-muntjes" and four Chinese copper cash. OJM (1923), p. 102; Not. (1878), p. $80 \mathrm{sq}$. [This is the only known find containing both Chinese copper cash and Sandaiwood Flower pieces.] 


\section{APPENDIX B: GOLD FINDS}

\section{West of Core Area I}

( $T j$ isondari, $T j i w i d e j$, Bandoeng, Preanger)

Several finds are reported from this area:

1. In 1888, 300 specimens of a gold coin. Identified as same as Cat., 1886, p. 34, no. 3; Netscher and van der Chijs, no. 119; Millies (1871), nos. 1-3. [Piloncito Class A.]

2. 700 similar coins were discovered in 1891. [Piloncito Class A].

3. A single specimen is reported for 1893. [Piloncito Class A.]

OJM (1914), p. 45; Not. (1888), p. 53 sq. and p. 72; Not. (1891), p. 45 sq.; Not. (1893), p. 137; Tijd. XXXVII (1894), p. 324; Not. (1898), p. 135.

4. (Tjipokoe, Singaparna, Tasik Malaja [Soekapoera], Preanger). Find of two gold rings, glass ball, two stone balls, round and square gold coins, in a green glazed pot. Identified as similar to Netscher and van der Chijs, nos, 121, 122, and 123; Millies $(1871), 8,9,10,11,12$. [References are to irregular silver.] This is actually the irregular gold find mentioned above, found in 1904, with square gold sheets having a flower pot design on obverse and reverse. OJM (1914), p. 77; Not. (1904), pp. 109 and 121 sq.

\section{Core Area I}

5. (Karang tengah, Bawang, Batang, Pekalongan). Find of two gold earrings, six small rings, a white stone and ten gold coins, found in an earthenware pot in the ground. OJM (1914), p. 139; Not. (1868), p. 63.

6. (Doekoehsalem, Slawi, Tegal, Pekalongan). Notice that a gold coin from the area is to be found in the Batavia [Jakarta] Museum. OJM (1914), p. 143; Not. $(1876)$, p. 104 .

7. (Former Residency of Tegal, Watoekoempel, Pemalang, Pekalongan). Three bronze bells, three fragments of a gold ring and four gold coins. Not. (1878), p. 34, mentions the coins were of "teerlingvormige" or "diestruck." Identified as van der Chijs (1896), p. 67, no. 1; Netscher and van der Chijs, no. $121=$ Millies (1871), no. 8; Netscher and van der Chijs, no. $121=$ Millies (1871), no. 7; Netscher and van der Chijs, no. $122=$ Millies (1871), no. 10; Netscher and van der Chijs, no. $123=$ Millies (1871), no. 12. [References are to irregular silver.] OJM (1914), pp. 163-64; Not. (1878), p. 34.

8. (Bandjaran, Pemalang, Pemalang, Pekalongan). Find of a gold coin in the Kali Tengah. Described in Not. (1904), p. 58, as a "knoopje" or "button" doubtless referring to a Piloncito coin. OJM (1914), p. 160; Not. (1904), p. 58.

9. (Bara Budur, Salaman, Magelang, Kedoe). Two gold coins. Refers to Millies (1871), P. 10 sq. and Plate I. [Probably Piloncito Class E.] OJM (1914), p. 273 .

10. (Nglorok, Pringsoerat, Temanggoeng, Kedoe). Two pairs of eardrops and one coin. Van der Chijs (1896), p. 67, no. 4; identified as same as Netscher and van der Chijs, no. 131[?]. [Piloncito Class A.] OJM (1914), PP. 287-88; Not. (1896), PP. 25 and 57.

11. (Former Residency of Japara, Semarang). Finds included nine gold coins. Identified as van der Chijs (1896), p. 67, no. 3; Netscher and van der Chijs, no. 119; Millies (1871), nos. 1, 2, 3. [Piloncito Class A.] OJM (1914), p. 208. 
12. (Grobogan, Semarang). Find of three gold rings, and two gold ear ornaments, with three gold coins in the shape of cubes, found in the ground. [Pi]oncito type.] OJM (1914), P. 199; Not. (1894), p. 79; Not. (1899), p. 2.

13. (Semarang, Semarang, Semarang, Semarang). Reference to van der Chijs (1896), p. 67, no. 2; Millies (1871), P. 8 and Plate I. Called "driehoekig." [Irregular gold; description in van der Chijs; Millies reference is to silver.]

(Prambanan, Prambanan, Mataram, Jogjakarta).

Two finds are reported from this area:

14. A find of 20 "muntstukjes." banan.

15. Another find of a gold coin in a stone box around the temple of PramOJM (1915), p. 53; Jaarboek VI (1939), p. 107.

16. (Tjandi Idjo, Brebah, Mataram, Jogjakarta). Find of two gold coins. Found in the deposit under the altar of the head temple of the Goenoeng Idjo. Described as "bolletjes" or globules. Identified as Cat. no. $5=$ Netscher and van der Chijs, no. 131. [Probably Piloncito type.] OJM (1915), p. 40; Not. $(1886)$, p. 182 sq.; Not. $(1887), 127,133$; Not. 25, pp. 70-71.

(Tjandi Kalasan, Brebah, Mataram, Jogjakarta).

Several finds are reported from this site:

17. Find of a gold coin with a stamped design. Diameter of $0.5 \mathrm{~cm}$. Jaarboek VI (1939), p. 105 , no. 6518.

18. Another find of a gold coin 1 ike no. 6518 along with six pieces of "bladgoud" or "sheetgold" clippings. Coins were $0.5 \mathrm{~cm}$ in diameter; gold pieces $0.2-$ $1 \mathrm{~cm}$ in diameter. From Tjandi Kalasan deposit no. 32 . (No. $6519 \mathrm{a}-\mathrm{g}$ ).

19. Third find of a gold, dish-shaped coin, diameter of $0.9 \mathrm{~cm}$, from the area around Tjandt Kalasan. Jaarboek V (1938), p. 127, no. $6251 \mathrm{e}$.

20. (Solo = Surakarta). Find of two sorts of gold coins found near the sugar factory of Tasikmadoe, of a type not known in Java previously. Not. (1921), p. 118; Not. 23 Jan. 1922, sub. III.

Core Area II

21. ( $T j$ andi Songgoriti). Find of gold coin, bow 7-shaped and stamped, and two pieces of clipped sheet gold. Jaarboek VI (1939), p. 108, nos, 6533 a-c.

(Tjodo Boeloel awang, Malang)

Two finds are reported from this area:

22. In Southwest Chinese stoneware pot, 135 ball-shaped gold coins. [Piloncito type.] oV (1937), p. 30.

23. Another find of eight gold coins, ball-shaped. [Piloncito type.] Found in a pot designated as no. 6724 . Diameter $0.7-0.8 \mathrm{~cm}$; total weight of 19gm. This would make the average weight of one coin $2.37 \mathrm{gm}$, or 1 masa. [Piloncito type.] Same references as 22.

East of Core Area II

24. (Lanas, Pradjekan, Bondowoso). Find of one gold coin and a gold hook. OV (1936), p. 15. 
APPENDIX C: MIXED GOLD AND SILVER FINDS

Core Area I

Note: At least one find from Semarang contains both Piloncito Class $A$ and Sandalwood Flower pieces. See Millites (1871), pp. 8 and 14.

1. (Wanasaba, Kedoe). Eight gold and a number of silver coins. OJM (1914), Pp. 355-56.

2. (Djepang, Tenggeles, Koedoes [Pati], Semarang [Japara]). Earthenware pot with ten gold and 193 silver coins. OJM (1914), p. 205; Not. (1876), PP. 90 and 101.

3. (Djembaran, Kajen, Pati, Semarang). One gold ring with the inscription Sri, three silver and two gold coins, found in the ground. OJM (1914), P. 201; Not. (1890), pp. 115 sq. and 170.

4. (Ngaloeran, Kaliwoengoe [Perboean], Kendal, Semarang). A pair of silver armrings and a gold snake's head, one silver band, four gold and 30 silver coins. OJM (1914), p. 192; Tijd. X (1861), p. 447.

5. (Getas, Salatiga, Salatiga, Semarang). One gold and two silver coins. OJM (1914), p. 182; Tijd. V (1856), p. 314; Not. (1875), pp. 98 and 128. 
APPENDIX D. FINDS OF CHINESE COPPER CASH AND NATIVE ISSUES

1. (Tjoeroeg, Djasinga, Buitenzorg). Found in the rubber town, Pasir Tomo b lock, 352 gobog. OV (1940), p. 34.

2. (Batavia, Wijk Pasarpisang). In a Chinese porcelain cup filled with coins: 11 gohog, 1 cent (Nederland, 1876), 1 cent (Nederl andsche-Indie, 1857), 1 kiping (United East India Company, 1787). OV (1940), p. 33.

3. (Soekanagara, Soekanagara, Tjiandjoer). In the kampong Tjiwitaligirang, were found 662 gobog. OV (1940), p. 34.

4. (Peundeuj, Tjikadjang, Garoet). Find of 1100 Chinese cash approximately $50 \mathrm{~cm}$. deep, along with one stone and one bronze pot. OV (1938), p. 18.

5. (Sigoetji, Bandar, Pekalongan). In a ricefield was found a red copper cooking pan with 15 gobog. OV (1940), p. 34.

6. (Tritikoelon, Tjilatjap). In the Moenggangsemangir block, in a yard or compound, about 2500 gobog. OV (1940), p. 34.

7. (Selandaka, Soempioeh, Banjoemas). In an earthenware pot, 4561 gobog. OV $(1940)$, p. 34 .

8. (Talaga, Talaga, Madjalingka, Pekalongan). Two large coffins found containing old Chinese copper cash. OJM (1913), p. 81.

9. (Boemlajoe, Boemiajoe, Pekalongan). Find of 2-3,000 Chinese cash and tin coins with Chinese, Javanese, and other sorts of inscriptions. OJM (1913), p. 51 .

10. (Demak, Demak). Find of 92 gobog. OV (1940), p. 35.

11. (Tjandi Kalasan, Brebah, Mataram, Jogjakarta). Photographs of dagob from temple site. OV (1929), p. 38, nos. 9419-9423.

12. (Tjandi Sari, Brebah, Mataram, Jogjakarta). Fragments of dagob. OV (1930), p. 108, nos. 1024-1026.

13. (Tobajan, Bantoel, Jogjakarta). In the hamlet Djoeragan, found 1585 kepeng. OV (1938), p. 20.

14. (Gadoengan, Karang Pandan, Sragen, Surakarta). 90 copper coins and one stone tool. OJM (1915), p. 103; Not. (1864), p. 188.

15. (Pandjeng, Ponorongo). A copper cookpot with earthenware pots and porcelain, along with 78 Chinese coins. OV (1939), p. 23.

16. (Besoek $i$ ). In a copper cooking pot, four porcelain jars, two pair silver armbands, and 52 copper coins. OJM (1923), p. 126; Not. (1889), p. 166h.

17. (Soemengko, Dero, Ngawi). Find of Chinese coins. OV (1937), p. 26.

18. (Tandjoengsari, Ngrambe, Ngawi). One Chinese coin and one Javanese "amuletpenning." OV (1937), p. 27; Jaarboek V (1938), p. 139; Not. (1913), p. 15.

19. (Takeran, Gorang gareng, Magetan, Madioen). Two copper cooking kettles with 30 Chinese cash dated to 995-1118. OJM (1915), p. 125; Not. (1892), p. 85 sq. 140.

20. (Madioen, Lorok, Patjitan, Madioen). Find of 500 coins. OJM (1915), p. 
21. (Geningan, Madioen). A copper pot found with old money inside. Not. (1915), p. 112.

22. (Watoe dangdang, Waroedjajeng, Berbek, Kediri). A bronze hanging clock (?) with a chain, and 2475 "Bal ische" coins. OJM (1915), p. 373; Not. (1904), p. 7 .

23. (Kemasan, Kediri). Find of 1860 Chinese coins. OV (1939), p. 23.

24. (Waroedjajeng, Berbek, Kediri). Two boxes with Chinese cash. OJM (1915), p. 374.

25. (Kalikonto, Djombang, Bareng, Kediri). An earthenware pot with a pair of coins. Uncertain description. Not. (1915), p. 95.

26. (Sidoardjo, Sidoardjo, Soerabaja). A large quantity of Chinese coins and tempelmunt or gobog. The newest Chinese cash pieces dated to 1119-1125. The gobog were identified as Millies no. 48. According to Moquette, the Wayang form of the figures on the temple tokens is 12-13th century. OJM (1915), p. 1169; Not. (1879), p. 65 sq.; Not. (1898), pp. 181, 191.

27. (Soekoredjo, Sidoardjo, Soerabaja). Find of 390 Chinese coins in a field. OV (1937), p. 29.

28. Wage, Krian, Sidoardjo, Soerabaja). A find of a copper pot and eight Chinese copper cash. OJM (1915), p. 180; Not. (1890), p. 84 sq.

29. (Djombang, Djombang, Djombang, Soerabaja). Find of a few coins of uncertain description. OJM (1915), Pp. 232-33.

30. (Koetoredjo, Toeban). In a stoneware crock from Kwangtung province in China (1350-1400), were found 2104 Chinese cash. OV (1939), p. 23.

31. (Soemberredjo, Djombang). A Targe number of Chinese cash found. OV (1939), p. 24 .

32. (Droedjoe, Toeren, Malang). In a ricefield in a bronze cooking pan and a bronze kettle, 390 Chinese cash. OV (1939), p. 24.

33. (Tlogomas, Malang). Find of 213 Chinese coins. OV (1937), p. 29.

34. (Pait, Poedjon, Malang). Along with a copper pan and a red copper bow 1 , 50 old Chinese cash. OV (1938), p. 23.

35. (Tj loemprit, Boeloelawang, Malang). In a ricefield 524 old Chinese coins found. OV (1938), p. 23.

36. (Swaroe, Malang, Malang, Pasoeroean). A metal beaker, a bronze lamp and about 200 Chinese coins found. OJM (1923), pp. 27-28; Not. (1881), p. 104k.

37. (Kaproe, Penangoenan, Malang, Pasoeroean). A box, in which was found a number of Chinese cash. OJM (1923), p. 38; Not. (1886), p. 130 sq.

38. (Bringing, Toeren, Malang, Pasoeroean). A find of five Celadon plates with Chinese cash. OJM (1923), P. 55; Not. (1919), p. 4.

39. (Ngoenoet, Panaraga, Panaraga, Madioen). Find of Chinese coins. OJM (1915), p. 127; Not. (1902), p. 107.

40. (Salak, Klakah, Loemadjang). Fragments of copper utensils and 368 gobog. OV (1940), pp. 39-40.

41. (Pangligoer, Soemenep, Soemenep, Madoera). Chinese cash find in an earthenware pot, around the year 1880, in the kampong Demala. OJM (1908), Pp. 8-20; OJM (1923), P. 131; Tijd. (1893), p. 240. 
42. (Andongsari, Amboeloe, Djember). In the hamlet Watoekebo, about $0.5 \mathrm{~m}$ deep, an earthenware pot with 50 old Chinese coins, ov (1938), p. 24.

43. (Gambirana, Tanggoe1, Djember, Besoeki). A porcelain pot with 350 Chinese coins found in the village. OJM (1923), p. 113; Not. (1898), p. 4.

45. (Tanggoel, Tanggoel, Djember, Besoek 1 ). Find of 129 pieces of Chinese cash. OJM (1923), p. 113; Not. (1898), p. 4.

46. (Bangsalan, Tanggoel, Djember, Besoek $i$ ). Find of 60 Chinese cash in Martaban jars. OJM (1923), p. 114; Not. (1898), p. 4.

47. (Soetja, Tamanan, Bondowoso, Besoek 1 ). In 1878, along with a metal pot and pan, were found 140 silver "Hindu-muntjes" and four Chinese copper cash. OJM (1923), p. 102; Not. (1878), p. 80 sq. 